University of Montana

ScholarWorks at University of Montana

\title{
The Contractarian Model of Arbitration and Its Implications for Judicial Review of Arbitral Awards
}

Paul F. Kirgis

Alexander Blewett III School of Law at the University of Montana, paul.kirgis@umontana.edu

Follow this and additional works at: https://scholarworks.umt.edu/faculty_lawreviews

Part of the Dispute Resolution and Arbitration Commons

Let us know how access to this document benefits you.

\section{Recommended Citation}

Kirgis, Paul F., "The Contractarian Model of Arbitration and Its Implications for Judicial Review of Arbitral Awards" (2006). Faculty Law Review Articles. 105.

https://scholarworks.umt.edu/faculty_lawreviews/105

This Article is brought to you for free and open access by the Faculty Publications at ScholarWorks at University of Montana. It has been accepted for inclusion in Faculty Law Review Articles by an authorized administrator of ScholarWorks at University of Montana. For more information, please contact scholarworks@mso.umt.edu. 
PAUL F. KIRGIS*

\section{The Contractarian Model of}

\section{Arbitration and Its Implications for Judicial Review of Arbitral Awards}

In an article that appeared as alternative dispute resolution, or ADR, was emerging as a topic of mainstream legal consideration, Paul Carrington addressed the different understandings of the "alternative" in ADR. ${ }^{1}$ He postulated that proponents of ADR unite under the banners of three primary aversions. First, some proponents seek an alternative to law itself. ${ }^{2}$ They resist the formalism and rigidity of legal solutions to personal and social problems. Second, some proponents seek an alternative to professionalism in law. ${ }^{3}$ They dislike the adversarialism that attorneys seem to bring to dispute resolution. Third, some proponents seek alternatives to traditional adjudicative procedures. ${ }^{4}$ They distrust a judicial system that they see as inefficient and callous to the real needs of participants.

Within the spectrum of ADR techniques, arbitration seems largely a response to the third concern. The disputants who favor arbitration are not necessarily averse to law and legal solutions, and they typically embrace lawyers as dispute resolution professionals. What they often want to avoid is the formality of traditional adjudicative process. In particular, they usually want a process made less

\footnotetext{
* Professor, St. John’s University School of Law. I am grateful to Chris Borgen, Elaine Chiu, Michael Perino, Susan Stabile, Brian Tamanaha, Stephen Ware, and Tim Zick for their helpful comments on this project, and to Dora Jimenez for her invaluable research assistance.

1 See Paul D. Carrington, Civil Procedure and Alternative Dispute Resolution, 34 J. LEGAL EDUC. 298 (1984).

2 Id. at 298.

${ }^{3}$ Id.

${ }^{4}$ Id.
} 
expensive through decreased use of pleadings, discovery, and motions, and they want a decision made by a professional with expertise in a field rather than by a lay jury. ${ }^{5}$

However, arbitration also carries the potential to respond to the first concern: the concern regarding the use of law to resolve disputes. According to one conventional way of thinking about the law, it is primarily a set of rules supplying norms of behavior. ${ }^{6}$ Those rules may be more or less determinate, and they may derive from any of a number of sources. But there seems to be broad consensus, at least among the public, that legal rules exist, that they constitute "the law," and that the job of legal actors is to consistently and fairly apply those rules.

Sometimes disputants want to avoid the rules that a court would be likely to apply to their dispute. For example, trading partners in a commercial relationship may want their dispute resolved by reference to industry custom rather than generally applicable rules of law. ${ }^{7}$ If they went to court, they could not be assured that the rules of their choice would be applied. By choosing arbitration, they can pick an arbiter who is more likely to apply those rules. ${ }^{8}$ To the extent the parties empower the arbitrator to decide their dispute without reference to the legal rules that a court would be likely to invoke, they make arbitration an alternative to law.

That scenario assumes that the parties have roughly equal bargaining power and are in a relationship that they expect to continue. The use of arbitration to avoid legal rules seems benign in

5 See Lisa Bernstein, Understanding the Limits of Court-Connected ADR: A Critique of Federal Court-Annexed Arbitration Programs, 141 U. PA. L. REV. 2169, 2243-47 (1993). Disputants may also value arbitration for its promise of confidentiality. Id. at 2240.

${ }^{6}$ See LaWrence M. Friedman, The Legal System: A Social Science PERSPECTIVE 1 (1975).

7 See Murray S. Levin, The Role of Substantive Law in Business Arbitration and the Importance of Volition, 35 AM. BUS. L.J. 105, 124 (1997).

8 See EDWARD BRUNET \& Charles B. CRAVER, Alternative Dispute Resolution: The Advocate's Perspective 324 (2d ed. 2001) ("The theory of the contracts to arbitrate New York textile disputes was simple-rather than go to court, let a trusted, expert third party who was knowledgeable in the trade and industry customs decide the dispute. Arbitrator expertise was primarily responsible for the success of these textile arbitrations ... .”); Lisa Bernstein, Opting Out of the Legal System: Extralegal Contractual Relations in the Diamond Industry, 21 J. LEGAL STUD. 115, 127 (1992) (stating that arbitrators decide complex cases in the diamond industry primarily "on the basis of trade custom and usage"); Soia Mentschikoff, Commercial Arbitration, 61 COLUM. L. REV. 846, 852-53 (1961) (explaining that the arbitrator's awareness of trade custom is a factor that enhances the predictability of arbitration). 
that situation. In other contexts, however, parties may seek to avoid law in ways designed to advantage them or disadvantage their contract partners. For example, many financial institutions would prefer to be free of legal restrictions in their dealings with customers, many employers would prefer to be free of discrimination laws, and many doctors and hospitals would prefer to be free of medical malpractice liability. These parties might jump at the chance to avoid otherwise-governing legal rules by using arbitration instead of formal adjudication. They might choose arbitration in the hope that an industry-sensitive arbitrator will ignore or downplay otherwise applicable legal rules favoring the weaker party. The prospect of arbitration as a means to avoid law in these situations seems far less palatable.

Arbitration has become increasingly common in cases involving precisely those circumstances. At the beginning of the twentieth century, arbitration was not widely used outside of commercial disputes involving merchants. ${ }^{9}$ For a variety of reasons, not least the rising cost of litigation, the use of arbitration expanded rapidly in the second half of the last century. ${ }^{10}$ The United States Supreme Court validated the use of binding contractual arbitration as a dispute resolution mechanism in many situations in which the parties have neither equal bargaining power nor an ongoing relationship. ${ }^{11}$ As a result, arbitration became widespread in consumer disputes, employer-employee relations, and virtually every other context in

9 See FRANCES KELlOR, AMERICAN ARBITRATION: ITS HISTORY, FUNCTIONS AND ACHIEVEMENTS 6 (Kennikat Press 1972) (1948); Jeffrey W. Stempel, A Better Approach to Arbitrability, 65 TUL. L. REV. 1377, 1380 (1991) (“The United States Arbitration Act . . . was written with the implicit assumption that it would be invoked by commercial actors having relatively equal bargaining power and emotive appeal to a jury.”); Zeb-Michael Curtin, Note, Rethinking Prima Paint Separability in Today's Changed Arbitration Regime: The Case for Inseparability and Judicial Decisionmaking in the Context of Mental Incapacity Defenses, 90 IOWA L. REV. 1905, 1910-13 (2005) (explaining that arbitration was limited to use among commercial actors at the time of the Federal Arbitration Act's (FAA) passage).

10 See Deborah R. Hensler, Our Courts, Ourselves: How the Alternative Dispute Resolution Movement Is Re-Shaping Our Legal System, 108 PENN ST. L. REV. 165, 167 n.11 (2003) (citing a report by the American Arbitration Association that "[f]rom 1990 to 2002, the AAA's caseload increased 379 percent”).

11 See, e.g., Gilmer v. Interstate/Johnson Lane Corp., 500 U.S. 20 (1991) (allowing arbitration for an employer-employee relationship); Rodriguez de Quijas v. Shearson/American Express, Inc., 490 U.S. 477 (1989) (allowing arbitration for an investor-broker relationship); Shearson/American Express, Inc. v. McMahon, 482 U.S. 220 (1987) (allowing arbitration of RICO claims). 
which parties order their relations by contract. ${ }^{12}$ The potential for the abusive avoidance of law increased correspondingly.

Despite a sustained chorus of academic concern, ${ }^{13}$ courts have largely failed to acknowledge the potential for this abuse. They have retained in the new contexts the strong presumption of deference to arbitral awards that grew up around commercial and labor arbitration. ${ }^{14}$ In all cases today, even those such as employment discrimination that involve important personal rights, courts resist calls to review awards to ensure that arbitrators follow the law. ${ }^{15}$ They pay lip service to the need for arbitration to protect those rights, ${ }^{16}$ but without effective judicial review, there are no assurances that arbitrators will get the law right.

The systemic decision to enforce arbitration awards without meaningful review amounts to a policy choice. At least implicitly, we believe that the benefits of an expedited dispute resolution mechanism exceed the costs of a less thorough exploration of legal rights-even in cases where the parties have radically different bargaining power.

This policy choice is backed by both analytical principle and legal doctrine. The analytical principle is the familiar ideal of freedom of contract. Courts venerate party autonomy. They tend to see extreme deference to arbitral awards as necessary to protect the parties’ choice

12 Jean R. Sternlight, Creeping Mandatory Arbitration: Is It Just?, 57 STAN. L. REV. 1631, 1638-40 (2005).

13 See, e.g., Reginald Alleyne, Statutory Discrimination Claims: Rights "Waived" and Lost in the Arbitration Forum, 13 HOFSTRA LAB. L.J. 381, 383 (1996) (arguing that the "Gilmer dicision carries alternative dispute resolution to excess"); Robert A. Gorman, The Gilmer Decision and the Private Arbitration of Public-Law Disputes, 1995 U. ILL. L. REV. 635, 678 (fearing that the "Gilmer decision ... represents the beginning of a potentially vast reallocation of jurisdiction over employment disputes from civil courts and administrative agencies to privately selected arbitrators”); Martin H. Malin, Privatizing Justice-But by How Much? Questions Gilmer Did Not Answer, 16 OHIO ST. J. ON DisP. RESOL. 589, 627 (2001) (positing that "[i]f courts do not review employment arbitration awards for errors of law, we risk transforming a system of public law into a system of private justice”); Stephen J. Ware, Default Rules from Mandatory Rules: Privatizing Law Through Arbitration, 83 MiNN. L. REV. 703, 731 (1999) (arguing that "the 'ground' for inarbitrability must be judged [in each case] on its substance, not merely its label”). But see Robert N. Covington, Employment Arbitration after Gilmer: Have Labor Courts Come to the United States?, 15 HOFSTRA LAB. \& EMP. L.J. 345, 406-08 (1998) (willing to accept the increased role of arbitration because it is a "finality-enhancing doctrine").

14 See infra notes 55-58 and accompanying text.

15 See infra notes 73-95 and accompanying text.

16 See Mitsubishi Motors Corp. v. Soler Chrysler-Plymouth, Inc., 473 U.S. 614, 628 (1985) (“[B]y agreeing to arbitrate a statutory claim, a party does not forgo the substantive rights afforded by the statute; it only submits to their resolution in an arbitral, rather than a judicial, forum.”). 
of arbitration as an alternative to adjudication. ${ }^{17}$ The legal doctrine comes from the Federal Arbitration Act (FAA), ${ }^{18}$ the primary statute governing judicial oversight of arbitration. The FAA provides no express authority for substantive review of awards. ${ }^{19}$ While courts have grafted some common-law grounds for review onto the FAA, those grounds are extremely limited. Courts point to the FAA as compelling extreme judicial deference to arbitral awards in all contexts.

It is probably not possible to demonstrate empirically whether the benefits of unreviewable arbitration exceed the costs, either in individual cases or in the aggregate. ${ }^{20}$ Participant surveys might tell some of the story, but too many intangible factors, such as the social utility of public and formal adjudication, come into play to make such a determination meaningful. At the end of the day, every policy argument in favor of arbitration without judicial review can be met by a contrary argument in favor of curtailing arbitration. ${ }^{21}$

The fact that the policy debate has no clear resolution makes resort to the principle of party autonomy and the doctrine of the FAA critically important. Those who favor the current system of virtually unlimited and unreviewable arbitration can forestall change -and even avoid engaging in a sustained policy discussion—by falling back on those defenses. While it is not possible to resolve the policy issues finally, it is possible to assess whether the principle of party autonomy, coupled with applicable legal doctrine, justifies the degree of deference courts have adopted. That is what I attempt in this Article. I argue that, at least in certain classes of cases, the principle of party autonomy requires greater judicial scrutiny of arbitral awards. I argue further that this result is doctrinally compelled by basic tenets of contract law that operate independently of-and cannot be preempted by -the FAA.

\footnotetext{
17 Prima Paint Corp. v. Flood \& Conklin Mfg. Co., 388 U.S. 395, 404 (1967) (deferring to "the unmistakably clear congressional purpose that the arbitration procedure, when selected by the parties to a contract, be speedy and not subject to delay and obstruction in the courts").

18 See 9 U.S.C. §§ 1-16 (2000 \& Supp. II 2001-2003).

19 See id. § 10.

${ }^{20}$ For a good recent exploration of the costs and benefits of arbitration both for individuals and society, see Sternlight, supra note 12.

21 See Covington, supra note 13, at 404 (“[E]rrors in law are important and arbitration opinions and awards should be subject to some sort of review. Finality of awards is also important, however, and simply to state two important competing values does not itself dictate how to strike a balance between them.”).
} 
In making these arguments, I rely on a particular model of arbitration-what I will call the contractarian model-that seems to animate the modern judicial attitude toward arbitration. ${ }^{22}$ In this model, the arbitrator is seen not as a substitute adjudicator, but as an agent of the parties tasked with interpreting the terms of their agreement. The arbitrator's decision is treated as if it were a contract term agreed upon by the parties. Since the award under this model is the equivalent of a contract term, a court interested in promoting party autonomy will hesitate to upset it. The court will focus on ensuring that the new "term" was properly "agreed upon"-that is, that the arbitrator did not exceed the scope of his agency and was not biased in some way. And in fact, that is precisely the type of review contemplated by the FAA. ${ }^{23}$

Viewed in these terms, the ritual conclusion that enforcing awards promotes party autonomy fails for two reasons. First, it assumes that the parties mutually agreed to an arbitral decision that might ignore their legal rights. In a contract of adhesion, we have no assurance that

22 Professors Edward Brunet and Stephen Ware have used the similar terms “contract model" or "contractual approach" respectively, in reference to arbitration. Edward Brunet, Replacing Folklore Arbitration with a Contract Model of Arbitration, 74 TUL. L. REV. 39, 46 (1999); Stephen J. Ware, Arbitration and Unconscionability After Doctor's Associates, Inc. v. Casarotto, 31 WAKE FOREST L. REV. 1001, 1002-06 (1996) [hereinafter Ware, Arbitration and Unconscionability]. Professor Brunet refers to a "contract model" of arbitration, which is characterized by adjudication-type procedures specified by the parties in the agreement to arbitrate. He distinguishes this model from "folklore arbitration," which is characterized by equitable decisions made by experts in a particular field without formal processes. Brunet, supra at 42-45, 47-51. Similarly, Professor Ware defines the "contractual approach" to arbitration as encompassing three principles: (1) courts should send parties to arbitration only where the parties agreed to arbitrate; (2) arbitration agreements should be enforced except on grounds for revocation of a contract; and (3) arbitrators should not be permitted to reach a result that the parties could not have reached through contract. See Stephen J. Ware, Interstate Arbitration: Chapter 1 of the Federal Arbitration Act, in BRUNET EL AL., ARBITRATION LAW IN AMERICA: A CRITICAL ASSESSMENT 88-126 (2006) [hereinafter Ware, Interstate Arbitration].

Despite the different emphases of their work, Professors Brunet and Ware both see a trend toward judicial deference to the parties' agreement as a hallmark of contract-based arbitration. That is a trend I emphasize as well. I use the term "contractarian model" in a more narrow way, however, to refer to attitudes toward the arbitrator's role, and more specifically, the nature of the award. I argue that, regardless of the terms of the agreement, courts have come to see the award as equivalent to a contract term. I distinguish this approach from one that views the award as equivalent to a judicial decision. I argue that the choice of a model has consequences for the degree of judicial scrutiny to be expected. Ultimately, I come to a conclusion close to Professor Ware's third principle above: that courts need to be more careful to ensure that awards do not violate basic rules of contract law.

23 See 9 U.S.C. § 10. 
that assumption is justified. The weaker party may be quite surprised to learn that an arbitrator can ignore the law without consequence. Courts avoid facing that problem by pointing to the absence of a meaningful standard of judicial review in the FAA. ${ }^{24}$ But a more probing doctrinal analysis reveals countervailing rules that compel substantive judicial review of awards.

Understood through the perspective of the contractarian model, an arbitrator's award is the equivalent of a contract term agreed upon by the parties. In some instances the decision ultimately rendered is different from the one a court would have issued by applying rules of law. If that decision is enforced, then the parties may be understood to have waived the legal rights that would have been protected by the application of the governing legal rule. In itself, this is not a radical result. Most legal rules are waivable, in the sense that we allow people to forgo the rights the rules would confer upon them if applied. That sort of waiver is uncontroversial when it is a free and informed choice and is done after the rights in question have matured.

It is a different thing to agree prospectively to forgo the rights that a legal rule might confer in the future. When parties enter into an arbitration agreement, they agree to abide by a decision to be made in the future about a dispute that has not yet arisen. The waiver occasioned by an arbitrator's award in derogation of law is both prospective, in the sense that it is made before the rights in question have matured, and ill-informed, in that the party does not know the effect of the waiver at the time it is made. This makes an "arbitral waiver" an extraordinary legal consequence and one that contravenes basic principles of contract law, at least in some situations.

To reach this conclusion is to conclude that the FAA cannot do the heavy lifting in support of unreviewable arbitration that has often been assumed. Section 2 of the FAA expressly incorporates state contract law by requiring courts to enforce arbitration agreements "save upon such grounds as exist at law or in equity for the revocation of any contract." 25 Interpreting this provision in Doctor's Associates,

24 See, e.g., Hill v. Norfolk \& Western Ry. Co., 814 F.2d 1192, 1194 (7th Cir. 1987) (stating that the only substantive review permitted under the FAA is into whether the arbitrator interpreted the contract); Stroh Container Co. v. Delphi Indus., Inc., 783 F.2d 743, 748-49 (8th Cir. 1986) (holding that “an arbitrator's conclusions on substantive matters may be vacated only when the award demonstrates a manifest disregard of the law where the arbitrators correctly state the law and then proceed to disregard it, if the award is otherwise irrational, or if any of the explicit grounds for vacation or modification set forth in sections 10 and 11 of the Act are present").

259 U.S.C. $\S 2$. 
Inc. v. Casarotto, the Supreme Court held that "generally applicable contract defenses, such as fraud, duress, or unconscionability, may be applied to invalidate arbitration agreements without contravening” the FAA. $^{26}$ If contract law effectively requires that arbitrators follow the law, as I will argue it often does, then the FAA cannot provide courts license to decline review of arbitral awards.

With that, the debate returns to the principle of party autonomy. Again, sometimes good reasons exist for enforcing arbitral decisions that effectively waive legal rights. Parties may knowingly and voluntarily choose arbitration precisely because they do not want their disputes resolved through the application of legal rules.

For a variety of reasons, we have made a societal commitment over the last several decades to promote alternative forms of dispute resolution. $^{27}$ We do not force people to litigate every dispute to a final judicial resolution; accordingly, we should also not make arbitration into a parallel system of litigation. Where parties genuinely want to resolve their dispute without resort to legal ruleswhere they voluntarily and knowingly choose to avoid law-we should normally let them do so. That is, after all, frequently what settlement entails.

That conclusion amounts to no more than saying that informed and voluntary waivers should be enforced. The problem is that in many cases the parties do not intend to forgo their legal rights. They choose arbitration because they want a more economical or more private forum in which to resolve the legal disputes that might arise between them. ${ }^{28}$ To enforce an arbitral award that is contrary to law in such a case is to impose an uninformed and unanticipated waiver on one or both parties. The real dilemma for courts is to distinguish the cases in which the parties genuinely envisioned arbitration as an alternative to law and those in which the parties wanted only an alternative to formal adjudicative process. Those in the former category do not require judicial review beyond that currently offered. But those in the

26517 U.S. 681, 687 (1996) (referring to section 2 of the FAA specifically). See also Sternlight, supra note 12, at 1644-45 (arguing that contractual and common-law approaches have been more successful than constitutional or federal statutory arguments challenging arbitration clauses); Ware, Arbitration and Unconscionability, supra note 22, at 1008-10 (explaining that after Doctor's Associates, state unconscionability law would be applied to the FAA).

27 See generally Jethro K. Lieberman \& James F. Henry, Lessons from the Alternative Dispute Resolution Movement, 53 U. CHI. L. REV. 424 (1986) (providing a history of, and the rationale behind, the growth of ADR in the 1970s and '80s).

28 See Bernstein, supra note 5, at 2240-43. 
latter category require some heightened standard to ensure a basic degree of compliance with law.

In order to avoid embroiling courts in factual disputes about the parties' prearbitration intentions, I will suggest that the selection of a standard of judicial review turn on objectively identifiable criteria. Those criteria should be used to determine a presumptive standard of review. This standard would apply in the absence of a clear manifestation of intent by the parties to select some other standard. The criteria should include considerations of bargaining power, the nature of the parties' relationship, and the legal rights and obligations at stake.

I will begin my analysis with a brief overview of the evolution of judicial attitudes toward arbitration. I will show both how courts have come to accept arbitration in virtually all contexts and how they have adopted a posture of extreme deference to awards. With that background in place, I will discuss the two competing models of arbitration - the first viewing arbitration as private adjudication and the second viewing it as a species of contract. I will then explain why the contractarian model better represents modern judicial attitudes toward arbitration. Next, I will discuss the law governing waivers of legal rights through contract to show how deference to arbitral awards can contravene generally applicable rules of contract formation. Finally, I will return to the topic of party autonomy and suggest a framework that courts can use in identifying the appropriate standard of review for awards.

ARBITRATION IN THE COURTS: A BRIEF HISTORY OF RAPID CHANGE

In the last one hundred years, courts in the United States moved from an attitude of skepticism towards arbitration to an attitude that validates agreements to arbitrate and defers to arbitrators as agents of the parties. The result is a modern dispute resolution environment in which arbitration agreements are enforced in virtually all contexts and arbitral awards are almost universally upheld.

\section{A. Common Law Attitudes Toward Arbitration}

Private arbitration predates the public court system. Early Roman and English law relied primarily on self-help; when parties mutually desired an adjudicated resolution to a dispute, they went to an 
arbitrator. ${ }^{29}$ Arbitration has, therefore, historically functioned as an adjudicative dispute resolution mechanism.

As the public court system arose and matured in England, it displaced private arbitration in providing the primary adjudicative function. Arbitrators represented unwelcome competition for common-law judges, whose compensation was tied in part to court fees. $^{30}$ Judges thus had powerful incentives to increase their jurisdiction and stifle competing dispute resolution mechanisms. ${ }^{31}$ As a result, until the twentieth century, courts tended to view arbitration skeptically. They typically refused to enforce agreements to arbitrate on the ground that the parties could not "oust" the court of its jurisdiction. $^{32}$

Once parties voluntarily submitted a dispute to arbitration, courts treated the resulting award as a binding obligation. ${ }^{33}$ But that did not

29 See 14 WILLIAM HOLDSWORTH, A HiSTORY OF ENGLISH LAW 187 (A.L. Goodhart \& H.G. Hanbury eds., 7th ed. 1956).

30 See William M. Landes \& Richard A. Posner, Adjudication as a Private Good, $8 \mathrm{~J}$. LEGAL STUD. 235, 241 (1979).

31 See Bernhardt v. Polygraphic Co. of Am., 350 U.S. 198, 211 n.5 (1956) (Frankfurter, J., concurring) (noting that English courts fought "for extension of jurisdiction-all of them being opposed to anything that would altogether deprive every one of them of jurisdiction”) (internal quotation marks omitted).

32 See Thompson v. Charnock, (1799) 101 Eng. Rep. 1310 (K.B.) (Kenyon, C.J.) (“It is not necessary, now, to say how this point ought to be determined if it were res integra, it having been decided again and again that an agreement to refer matters in difference to arbitration, is not sufficient to oust courts of law and equity of their jurisdiction.”); Kill v. Hollister, (1746) 95 Eng. Rep. 532 (K.B.); Vynior's Case, (1609) 77 Eng. Rep. 595 (K.B.). Early American courts adopted the same rule and maintained it throughout the nineteenth century. See Meacham v. Jamestown, Franklin \& Clearfield R.R. Co., 105 N.E. 653 (N.Y. 1914) (Cardozo, J.) ("If jurisdiction is to be ousted by contract, we must submit to the failure of justice that may result from these and like causes. It is true that some judges have expressed the belief that parties ought to be free to contract about such matters as they please. In this state the law has long been settled to the contrary."); Hurst v. Litchfield, 39 N.Y. 377, 379 (1868) ("Such stipulations [to arbitrate] are regarded as against the policy of the common law, as having a tendency to exclude the jurisdiction of the courts, provided by the government with ample means to entertain and decide all legal controversies.”) .

33 See Tankersley v. Richardson, 2 Stew. 130, 132 (Ala. 1829) (“The adjustment of controversies and suits by arbitration, is a species of remedy much favored by legislation; so much so, that, not only what can be, is intended in its favor, but it will not be permitted to be impugned for any extrinsic cause; unless it be founded in corruption, partiality, or other undue means.”); Brush v. Fisher, 38 N.W. 446, 448 (Mich. 1888) (“Courts . . . favor awards made by tribunals of the parties' own choosing, and are reluctant to set them aside, and every presumption will be made in favor of their fairness, and the burden of proof is upon the party seeking to set them aside, and the proof must be clear and strong.") (citations omitted); Winship v. Jewett, 1 Barb. Ch. 173, 184-85 (N.Y. Ch. 1845) ("[T]he award, if made in good faith, is conclusive upon the parties .... Neither will it constitute 
mean that awards were enforceable as judgments. Where a losing party to arbitration refused to comply with the award, the prevailing party's only option at law was to sue in either assumpsit or debt to recover on the obligation. ${ }^{34}$ That option was little better than suing on the underlying dispute. ${ }^{35}$ A better alternative was to sue in equity for specific performance of the obligation. ${ }^{36}$

A losing party seeking to avoid its obligations under an award had no option at law. ${ }^{37}$ Its only choice was to seek specific relief from the obligation in a court of equity. ${ }^{38}$ The equity courts analogized to the law of contract. They held that they could overturn an award only on the grounds for rescission of a contract, most notably fraud or mistake, or on a showing of bias by the arbitrator. ${ }^{39}$ Most courts applying that standard gave great deference to arbitrators' awards, summarily rejecting attempts to vacate awards not supported by strong evidence of fraud or partiality. ${ }^{40}$

any defence [sic] . . . to show that after the award had been published, [the arbitrator] dissented from it.”).

34 See Bruce H. Mann, The Formalization of Informal Law: Arbitration Before the American Revolution, 59 N.Y.U. L. REV. 443, 447 (1984).

35 See id.

36 See id.

37 See Newland v. Douglass, 2 Johns. 62, 63 (N.Y. Sup. Ct. 1806) (“The evidence was inadmissible, and a suit at law will not lie to re-examine the merits of an award. A court of chancery may correct a palpable mistake or miscalculation made by the arbitrators, or relieve against their partiality or corruption. But there is no such remedy at law, in a case of submission, not within the statute.”) (citations omitted).

38 See Herrick v. Estate of Belknap, 27 Vt. 673, 683-84 (1854) (“We may here, perhaps, look into the general rules of decision in courts of equity, which must govern this case. The claim put forth in the bill, being either mistake or fraud in the estimates, is one clearly of equity cognizance. Fraud, accident, and mistake form appropriate branches of the general jurisdiction of the court of chancery in England and in this state.”).

39 See id.

40 See, e.g., Davy's Ex'rs v. Faw, 11 U.S. 171, 174 (1812) (“[J]udges chosen by the parties themselves as well as those who are constituted by law, ought to be exempt from all imputation of partiality or corruption; . . . corrupt motives are not lightly to be ascribed to the arbiter, nor is partiality to be attributed to him on account of difference of opinion with respect to the decision he has made.”); Port Huron \& Nw. Ry. Co. v. Callanan, 34 N.W. 678, 679 (Mich. 1887) ("There is power in a court of equity to relieve against awards in some cases where there has been fraud and misconduct in the arbitrators, or they have acted under manifest mistake, and perhaps in some defined and undefined cases. But it is evident that there are great objections to any general interference by courts with awards.”); Campbell v. Western, 3 N.Y. Ch. Ann. 84 (Ch. 1832) (declining to vacate award on grounds of legal error in the admission of evidence where there was no evidence of fraud or bias). 
A significant number of nineteenth-century courts sitting in equity, however, used mistake grounds to exercise relatively extensive review of arbitral awards. ${ }^{41}$ While simultaneously affirming the power of arbitrators to decide disputed questions of law and of fact, these courts vacated awards for mistakes of law and fact provided the mistake appeared on the face of the award. ${ }^{42}$ In the words of Justice Story:

In regard to a mistake of the arbitrators, it may be in a matter of fact, or in a matter of law. If, upon the face of the award, there is a plain mistake of law, or of fact, material to the decision, which misled the judgment of the arbitrators, there can be little or no reason to doubt that courts of equity will grant relief.

Story emphasized that a mistake of law would constitute grounds for relief only if the arbitrators intended to rely on the legal rule. ${ }^{44}$ In contrast, "[i]f they admit the law, but decide contrary thereto upon principles of equity and good conscience," the award could not be set aside. ${ }^{45}$ Furthermore, arbitrators' decisions “upon a doubtful point of law, or in a case where the question of law itself is designedly left to their judgment and decision, will generally be held conclusive." ${ }^{46}$ In those latter two situations, no "mistake" would have been made, so no ground for vacatur would exist.

This doctrine of mistake gave courts, as a practical matter, relatively broad leeway to overturn awards. For example, in Tillard's Lessee v. Fisher, ${ }^{47}$ the plaintiff brought an ejectment action to recover property from the defendant, who had occupied the disputed property for more than twenty years. The arbitrators found for the plaintiff. The court set aside the award as being contrary to law on its face because the arbitrators failed to recognize the running of the statute of limitations. $^{48}$

41 But see Burchell v. Marsh, 58 U.S. 344, 350 (1855) ("Courts should be careful to avoid a wrong use of the word 'mistake,' and, by making it synonymous with mere error of judgment, assume to themselves an arbitrary power over awards.”).

42 See, e.g., Kleine v. Catara, 14 F. Cas. 732 (C.C.D. Mass. 1814) (No. 7869); White Star Mining Co. v. Hultberg, 77 N.E. 327 (Ill. 1906); Heuitt v. State ex rel. Brown, 6 H. \& J. 95 (Md. 1823).

432 JOSEPH STORY, COMMENTARIES ON EQUITY JURISPRUDENCE § 1453, at 791 (11th ed. 1873).

44 Id. § 1455, at 792.

45 Id. § 1455, at 792-93.

46 Id.

473 H. \& McH. 118 (Md. 1793).

48 Id. at 121. 
By refusing to enforce arbitration agreements and imposing a relatively robust doctrine of review of arbitral awards, eighteenth- and nineteenth-century common-law courts signaled a faith in traditional legal forms and a suspicion of alternatives. In keeping with the public sentiment of the time, these courts venerated both common-law process and, more importantly, the jury. ${ }^{49}$ For them, the loss of a jury trial was the loss of one of the most fundamental rights. ${ }^{50}$ The prospective waiver of such a fundamental right was anathema, and it was simply disallowed.

\section{B. The Federal Arbitration Act and the Courts' Reaction}

In 1925, Congress enacted the Federal Arbitration Act ${ }^{51}$ with the express purpose of abrogating judicial resistance to the enforcement of arbitration agreements. ${ }^{52}$ The FAA confers a right to apply to a federal district court to enforce an arbitration agreement in a "contract evidencing a transaction involving [interstate] commerce." 53 A party seeking to enforce an arbitration agreement may move to compel a reluctant party to proceed with arbitration. ${ }^{54}$ Alternatively, a party may move to stay litigation if litigation has already been commenced. $^{55}$ The FAA also provides a mechanism for judicial enforcement of awards. ${ }^{56}$ The ways courts reacted to the provisions requiring enforcement of arbitration agreements and the provision for enforcement of awards reveal their evolving attitudes toward arbitration.

\footnotetext{
49 See supra note 32 for examples of these cases.

50 See Bank of Columbia v. Okely, 17 U.S. 235, 243 (1819) (“[T]his Court would ponder long, before it . . . produced a total prostration of the trial by jury, or even involved the defendant in circumstances which rendered that right unavailing for his protection.”).

519 U.S.C. $\S 1$ (2000). When enacted, the FAA was called the United States Arbitration Act. Kenneth F. Dunham, Sailing Around Erie: The Emergence of a Federal General Common Law of Arbitration, 6 PEPP. DiSP. RESOL. L.J. 197, 205 (2006).

52 Allied-Bruce Terminix Cos., Inc. v. Dobson, 513 U.S. 265, 270 (1995) (“[T]he basic purpose of the Federal Arbitration Act is to overcome courts' refusals to enforce agreements to arbitrate.”).

539 U.S.C. $\S 2$.

54 Id. § 4 .

55 Id. $\S 3$.

56 See id. § 9.
} 


\section{The Enforcement of Arbitration Agreements}

For a number of years after the enactment of the FAA, courts continued to see arbitration as, at best, a second-class alternative to formal adjudication. Consequently, they initially interpreted the FAA narrowly. The Supreme Court's 1953 decision in Wilko v. Swan ${ }^{57}$ is the most prominent example of that mindset. Wilko addressed the application of the FAA to a dispute arising under the securities laws. An investor argued that he should not be required to arbitrate his fraud claims against a brokerage despite the existence of an arbitration clause in his brokerage agreement. ${ }^{58}$ He based this argument on a provision of the Securities Act of 1933 declaring void any "condition, stipulation, or provision binding any person acquiring any security to waive compliance with any provision" of the Act. ${ }^{59}$ He argued that arbitration "lacks the certainty of a suit at law under the Act to enforce his rights" and that the arbitration clause effectively waived compliance with the provision of the Act conferring concurrent jurisdiction on the district courts and state courts. $^{60}$

The Supreme Court refused to compel arbitration of the Securities Act claims. ${ }^{61}$ The Court focused on the inadequacy of arbitration as a substitute for formal adjudication. ${ }^{62}$ Notably, it never contemplated that an arbitrator would be free to ignore the law. Instead, the Court emphasized that the arbitrators would not have a judge to instruct them on the law. ${ }^{63}$ It further stated that even conceding arbitrators' obligation to apply the law, they would be under no obligation to produce a reasoned opinion allowing for meaningful judicial review. $^{64}$ On that basis, the Court held that the Securities Act precluded enforcement of the arbitration agreement. ${ }^{65}$

During this period, the Court threw its support behind arbitration in cases that did not involve statutory claims. The Steelworkers trilogy

57346 U.S. 427 (1953), overruled by Rodriquez de Quijas v. Shearson/American Express, Inc., 490 U.S. 477 (1989).

58 Id. at 429.

59 Id. at 430 n.6, 432.

60 Id. at $432-33$.

$61 \mathrm{Id}$. at 438.

62 Id. at 436-37.

$63 \mathrm{Id}$. at 436.

${ }^{64} \mathrm{Id}$. at $436-37$.

65 Id. at 438. 
cemented arbitration as the primary mechanism for resolving labormanagement disputes. ${ }^{66}$ Further, Prima Paint Corp. v. Flood \& Conklin Manufacturing Co. ${ }^{67}$ confirmed the broad enforceability of arbitration agreements in commercial cases by holding that even the issue of fraud in the inducement of the agreement to arbitrate must be decided by the arbitrator. ${ }^{6}$

Still, the Court remained hesitant about enforcing arbitration agreements where statutory rights were at issue. Alexander $v$. Gardner-Denver Co. ${ }^{69}$ seemed to reinforce Wilko's antipathy toward the arbitration of statutory claims. In Gardner-Denver, an employee covered by a collective bargaining agreement had arbitrated an employment discrimination grievance. ${ }^{70}$ The arbitrator ruled against him, and he then filed a lawsuit under Title VII of the Civil Rights Act of $1964 .^{71}$ The Supreme Court held that the arbitration did not affect his right to file suit because the claims arising under the bargaining agreement were "distinctly separate" from the statutory claims. ${ }^{72}$ The Court concluded that "[a]rbitral procedures, while well suited to the resolution of contractual disputes, make arbitration a comparatively inappropriate forum for the final resolution of rights created by Title VII." ${ }^{73}$ In reaching that conclusion, the Court noted several reasons why arbitration is an inferior procedural forum. These included arbitrators' potential lack of specialized legal knowledge, the informality of arbitration procedures, and the absence of mandatory written opinions. ${ }^{74}$

Faced with a clash between the Steelworkers trilogy's principle of arbitrability of labor disputes and Wilko's principle of nonarbitrability of statutory claims, the Gardner-Denver Court followed Wilko. The Court saw the statutory rights at issue as too important to commit to an inferior alternative process, even if that process arose out of a collective bargaining agreement. But the Court's reticence did not last long. In Scherk v. Alberto-Culver Co., ${ }^{75}$ decided the same year as

66 See United Steelworkers v. Warrior \& Gulf Navigation Co., 363 U.S. 574 (1960).

67388 U.S. 395 (1967).

68 Id. at $403-04$.

69415 U.S. 36 (1974).

70 Id. at $40-42$.

${ }^{71}$ Id. at $42-43$.

72 Id. at 50.

73 Id. at 56.

74 See id. at 57-58.

75417 U.S. 506 (1974). 
Gardner-Denver, a German citizen sought to enforce an arbitration agreement after he was sued by an American company for fraud under section 10(b) of the Securities Exchange Act of $19344^{76}$ The Supreme Court held the agreement enforceable and distinguished Wilko. The Court concluded that the nature of the statutory rights at issue was different because the Securities Exchange Act of 1934 implied a private right of action whereas the Securities Act of 1933 expressly provided a "special right."77 It also found an important distinction in the fact that the transaction in Scherk involved parties to an international agreement, whereas Wilko involved a private U.S. citizen suing other U.S. citizens. ${ }^{78}$

Because the Scherk Court refused to overturn Wilko, it left an anomaly in which claims asserted under the Securities Act of 1933 were not arbitrable, but claims asserted under the Securities Exchange Act of 1934 were arbitrable. It also left the Court's position on arbitrability generally unclear. The Court seemed to announce a policy in Scherk favoring arbitration even in statutory cases. At the same time, it seemed to backtrack in Gardner-Denver from its established policy of favoring arbitration in labor disputes.

By the mid-1980s, however, the composition of the Supreme Court had changed, and beginning with Mitsubishi Motors Corp. v. Soler Chrysler-Plymouth, Inc., ${ }^{79}$ the Court firmly committed itself to arbitrability in virtually every context. Mitsubishi, like Scherk, involved a dispute arising out of an international commercial agreement. $^{80}$ But instead of securities fraud, the claims alleged antitrust violations. ${ }^{81}$ The Supreme Court held the antitrust claims arbitrable, finding that the statutory rights at issue could be "effectively vindicated" in arbitration. ${ }^{82}$ Two years later, in Shearson/American Express, Inc. v. McMahon, ${ }^{83}$ the Court extended Scherk by enforcing an arbitration clause in a case alleging gardenvariety fraud claims against a securities broker under the Securities

\footnotetext{
${ }^{76} \mathrm{Id}$. at 509.

77 Id. at $513-14$

$78 \mathrm{Id}$. at 515.

79473 U.S. 614 (1985).

80 Id. at $616-17$.

81 Id. at $624-25$.

82 Id. at $636-37$.

83482 U.S. 220 (1987).
} 
Exchange Act of 1934 and RICO. ${ }^{84}$ Two years after that, in Rodriguez de Quijas v. Shearson/American Express, Inc., ${ }^{85}$ the Court finally put Wilko to rest by holding claims under the Securities Act of 1933 arbitrable. ${ }^{86}$ And in the 1991 case Gilmer v. Interstate/Johnson Lane Corp., ${ }^{87}$ the Court enforced an arbitration clause in a dispute involving employment discrimination claims under the Age Discrimination in Employment Act of $1967 .^{88}$ That decision crippled Gardner-Denver, without overruling it, by limiting it to cases involving parties covered by a collective bargaining agreement. In each of these decisions, the Court rejected the "suspicion of arbitration" and emphasized arbitration's effectiveness in vindicating statutory rights. $^{89}$

Since the early 1990s, the Court has remained steadfast in its support for arbitration as an alternative to formal adjudication. It has recognized only one limitation on arbitrability: cost. In Green Tree Financial Corp.-Alabama v. Randolph, ${ }^{90}$ a home purchaser argued that she should not have to arbitrate her fraud claims against her lender. ${ }^{91}$ She asserted that the cost of arbitration would be so high it would dissuade her and others like her from taking action to enforce statutory rights. ${ }^{92}$ The Supreme Court found a lack of evidence in the record to show how expensive arbitration would be, but it acknowledged that a claim of this type might have validity: "It may well be that the existence of large arbitration costs could preclude a litigant such as Randolph from effectively vindicating her federal statutory rights in the arbitral forum." 93 Lower courts have relied on Green Tree to refuse enforcement of fee-splitting provisions in arbitration clauses that would have the effect of imposing costs on

\footnotetext{
${ }^{84} \mathrm{Id}$. at 223. The aggrieved investors alleged "fraudulent, excessive trading on respondents' accounts and ... making false statements and omitting material facts from the advice given to respondents." Id.

85490 U.S. 477 (1989).

${ }^{86} \mathrm{Id}$. at 485 (explicitly overruling Wilko).

87500 U.S. 20 (1991).

88 Id. at 35.

89 See Rodriguez de Quijas, 490 U.S. at 483; Gilmer, 500 U.S. at 30; McMahon, 482 U.S. at 226.

90531 U.S. 79 (2000).

91 Id. at 83-84.

92 Id. at 84.

93 Id. at 90 .
} 
arbitration claimants that would exceed the court costs a litigant would be likely to face. ${ }^{94}$

In sum, over the last two decades the Supreme Court has removed virtually every obstacle to arbitration. Any claim, including statutory claims under the discrimination laws, is potentially arbitrable. And any party, including those with radically unequal bargaining power, can be held to an arbitration agreement. The only current limitation appears to be cost. The stronger party apparently may not force the weaker to bear the cost of the arbitration if that cost would deter the other party from seeking vindication of important legal rights.

These developments represent a dramatic change in the way courts view themselves and the judicial dispute resolution system. The Supreme Court no longer sees arbitration as an inferior substitute for formal adjudication. To the contrary, it has embraced the alternative to the very system at whose pinnacle it sits. Indeed, the Supreme Court seems to prefer arbitration to adjudication.

\section{The Enforcement of Arbitral Awards}

The starting point for discussion of standards of judicial review of arbitral awards is the FAA, which in section 10 contains a list of four grounds for vacating arbitral awards:

(1) where the award was procured by corruption, fraud, or undue means;

(2) where there was evident partiality or corruption in the arbitrators, or either of them;

(3) where the arbitrators were guilty of misconduct in refusing to postpone the hearing, upon sufficient cause shown, or in refusing to hear evidence pertinent and material to the controversy; or of any other misbehavior by which the rights of any party have been prejudiced; or

(4) where the arbitrators exceeded their powers, or so imperfectly executed them that a mutual, final, and definite award upon the subject matter submitted was not made.

\footnotetext{
94 See, e.g., Shankle v. B-G Maint. Mgmt. of Colo., Inc., 163 F.3d 1230, 1235 (10th Cir. 1999) (holding that a fee-splitting clause requiring claimant to pay one-half of arbitration costs "failed to provide an accessible forum in which [claimant] could resolve his statutory rights").

959 U.S.C. $\S 10$ (2000 \& Supp. II 2001-2003).
} 
Because the Supreme Court has held that the FAA preempts virtually all state arbitration law ${ }^{96}$ (absent an express agreement by the parties to invoke it), ${ }^{97}$ and because section 10 appears on its face to provide the exclusive grounds for vacating awards, no other test of judicial review seems necessary.

Nevertheless, the Supreme Court and every circuit court have found grounds for overturning awards that are not specifically mentioned in section $10 .{ }^{98}$ Three separate, non-statutory grounds for review have emerged: the "essence" test, the public policy test, and the test for legal error usually formulated in terms of "manifest disregard" of the law.

The "essence" test comes from United Steelworkers v. Enterprise Wheel \& Car Corp., ${ }^{99}$ one of the cases in the Steelworkers trilogy, in which the Court said that an "award is legitimate only so long as it draws its essence from the collective bargaining agreement." "100 By that, the Court apparently meant that the award must be arguably contemplated by an agreement and not simply contrived by the arbitrator from other sources. As the Court said in United Paperworkers International Union v. Misco, Inc.: ${ }^{101}$

[T]he arbitrator's award settling a dispute with respect to the interpretation or application of a labor agreement must draw its essence from the contract and cannot simply reflect the arbitrator's own notions of industrial justice. But as long as the arbitrator is even arguably construing or applying the contract and acting within

\footnotetext{
96 See Citizens Bank v. Alafabco, Inc., 539 U.S. 52, 56 (2003) (holding that the "FAA encompasses a wider range of transactions than those actually 'in commerce'"); AlliedBruce Terminix Cos., Inc. v. Dobson, 513 U.S. 265, 273-74 (1995) (holding that FAA reaches any contract "affecting” interstate commerce); Southland Corp. v. Keating, 465 U.S. 1, 11 (1984) (holding that state law invalidating certain arbitration agreements violates the Supremacy Clause).

97 See Volt Info. Scis., Inc. v. Board of Trs. of Leland Stanford Junior Univ., 489 U.S. 468, 479 (1989) (noting that "the FAA's primary purpose [is] ensuring that private agreements to arbitrate are enforced according to their terms").

98 The "exceeded powers" clause of section 10 is arguably broad enough to encompass a wide range of grounds for vacating awards, and some courts have referred to it in applying what are essentially judicially derived standards of review. See Stephen L. Hayford, Law in Disarray: Judicial Standards for Vacatur of Commercial Arbitration Awards, 30 GA. L. REV. 731, 756-62 (1996). For purposes of this Article, I treat any test not explicitly stated in section 10 as a non-statutory ground.

99363 U.S. 593 (1960).

$100 \mathrm{Id}$. at 597.

101484 U.S. 29 (1987).
} 
the scope of his authority, that a court is convinced he committed serious error does not suffice to overturn his decision.

Lower courts have elaborated. The Fifth Circuit has said that, for an award to draw its essence from a contract, it "must have a basis that is at least rationally inferable, if not obviously drawn, from the letter or purpose of the . . . agreement. . . . [T] he award must, in some logical way, be derived from the wording or purpose of the contract." 103

Awards have been found not drawn from the essence of a contract primarily when the arbitrator ignored the plain language of the agreement. In Sears, Roebuck \& Co. v. Teamsters Local 243, ${ }^{104}$ the Sixth Circuit refused to enforce an award granting reinstatement to employees when an arbitrator ignored plain language in their employment contract. ${ }^{105}$ The arbitrator awarded back pay to the employees whose jobs had been subcontracted out even though plain language in the contract gave the employer the right to subcontract work. ${ }^{106}$ The court emphasized that "an arbitrator may construe ambiguous contract language, but lacks authority to disregard or modify plain or unambiguous contract provisions."107 Because most disputes do not involve contract language that is unambiguous, the essence test seldom provides a basis for overturning awards.

In addition to validating the essence test, Misco recognized and refined a second non-statutory ground for reviewing awards: public policy. ${ }^{108}$ The Court in Misco upheld an arbitrator's award reinstating an employee who had been discharged for violating a company rule against possession of drugs on company property. ${ }^{109}$ The employee had been caught in the backseat of a car in the

\footnotetext{
102 Id. at 38.

103 Anderman/Smith Operating Co. v. Tenn. Gas Pipeline Co., 918 F.2d 1215, 1218 (5th Cir. 1990) (alteration in original) (citation omitted). 575 (6th Cir. 1979); Local Union No. 89 v. Hays \& Nicoulin, 594 F.2d 1093 (6th Cir. 1979); Amanda Bent Bolt v. UAW Local 1549, 451 F.2d 1277 (6th Cir. 1971)).

108 Initially, "public policy” was used as a means to review awards by the Court in 1983. See W.R. Grace \& Co. v. Local 759, Int'l Union of United Rubber, Cork, Linoleum \& Plastic Workers, 461 U.S. 757, 766 (1983) (holding that "a court may not enforce a collective-bargaining agreement that is contrary to public policy”) (citing Hurd v. Hodge, 334 U.S. 24, 34-35 (1948)).

109 United Paperworkers Int’l Union v. Misco, Inc., 484 U.S. 29, 33-35 (1987).
} 
company parking lot with marijuana smoke in the air and a lighted marijuana cigarette in the front-seat ashtray. ${ }^{110}$ The Court first concluded that none of the express grounds in section 10 warranted vacating the award because there was no evidence of affirmative misconduct by the arbitrator. ${ }^{111}$ Then it acknowledged that an award might be set aside even in the absence of those grounds if it violated public policy. ${ }^{112}$

The Court had mentioned the public policy ground before, ${ }^{113}$ and lower courts had applied it for years. ${ }^{114}$ But much confusion existed about the nature of the policy that had to be violated in order to justify vacatur. Some lower courts had been vacating awards based on generalized conclusions that the award contravened amorphous public policy goals. ${ }^{115}$ The Court in Misco explained that such a policy must "be ascertained 'by reference to the laws and legal precedents and not from general considerations of supposed public interests.", 116 It also required that the award "explicitly conflict" with that policy. ${ }^{117}$ The Court recognized that it might be a bad idea to allow employees to work with heavy machinery when they have used drugs on company property. But it concluded that the arbitrator's award to that effect did not conflict with any clearly defined public policy. ${ }^{118}$

In Eastern Associated Coal Corp. v. United Mine Workers, ${ }^{119}$ the Court refined the public policy test further while refusing to vacate an award reinstating a truck driver who twice tested positive for marijuana. ${ }^{120}$ The Court addressed whether sufficient grounds for

$110 \mathrm{Id}$. at 33. However, the arbitrator had refused to consider that evidence because it was discovered after the decision to terminate had been made. Id.

111 Id. at 40 .

112 Id. at 43 (" [A] court may refuse to enforce a collective-bargaining agreement when the specific terms contained in that agreement violate public policy.”).

113 See W.R. Grace \& Co., 461 U.S. at 766.

114 See Ann C. Hodges, Judicial Review of Arbitration Awards on Public Policy Grounds: Lessons from the Case Law, 16 OHIO ST. J. ON DISP. RESOL. 91, 95 (2000) (collecting seventy-three cases between 1960 and 1988 where the public policy argument was the primary claim).

115 Id. at 101-15 (discussing how different circuit courts deal with the public policy argument generally).

116 United Paperworkers Int’l Union v. Misco, Inc., 484 U.S. 29, 43 (1987) (quoting Muschany v. United States, 324 U.S. 49, 66 (1945)).

117 Id.

118 Id. at 44-45.

119531 U.S. 57 (2000).

120 Id. at 65-66. 
vacatur are present when an award is "contrary to public policy as ascertained by reference to positive law" or whether the award must affirmatively "violate" positive law. ${ }^{121}$ The Court refused to adopt the latter standard as a firm rule. ${ }^{122}$ However, it emphasized the narrow scope of the public policy ground and suggested that it would be very rare for an award to warrant vacatur on public policy grounds without violating positive law. ${ }^{123}$ It concluded that the award did not merit vacatur because neither Congress nor the relevant regulatory agencies had expressly prohibited an employer from allowing an employee who tested positive for drugs to remain on the job. ${ }^{124}$

Eastern Associated Coal establishes an extremely narrow ground for public policy review of arbitral awards. Apparently, a party seeking to vacate an award will have to identify a specific rule of law violated by the award. In other words, the party must show that the award, if made a contract term, would have rendered the contract unenforceable as illegal. That is a high burden to meet. In fact, very few cases since Eastern Associated Coal have found public policy grounds sufficient to vacate awards, and most of these have come from state courts. ${ }^{125}$

The essence test and the public policy test deal with the extreme cases in which an arbitrator either ignores contract language or enters an award that directly violates a rule of positive law. Nevertheless, most courts, including the Supreme Court, have indicated a willingness to consider arguments that an award is legally wrong, even if it is derived in some way from contract language and does not violate public policy. A number of formulations have emerged for identifying remediable arbitral error in these circumstances including "manifest disregard," "completely irrational," and "arbitrary and capricious." By far the most commonly employed is the "manifest disregard" test, which originated in dicta in Wilko. ${ }^{126}$

121 Id. at 63

122 Id. at 67

123 Id.

124 Id. at 66-67.

125 See Chicago Fire Fighters Union Local No. 2 v. City of Chicago, 751 N.E.2d 1169 (Ill. App. Ct. 2001); City of Brooklyn Center v. Law Enforcement Labor Servs., Inc., 635 N.W.2d 236 (Minn. Ct. App. 2001); Buffalo Police Benevolent Ass'n v. City of Buffalo, 830 N.E.2d 308 (N.Y. 2005).

126 See Wilko v. Swan, 346 U.S. 427, 436-37 (1953) overruled by Rodriguez de Quijas v. Shearson/American Express, Inc., 490 U.S. 477 (1989). The only circuit not to adopt some form of the manifest disregard test is the Seventh Circuit. See George Watts \& Son, Inc. v. Tiffany \& Co., 248 F.3d 577 (7th Cir. 2001). The court in Watts did not conclude 
In responding to the argument that arbitration provided an equivalent process to adjudication, the Court in Wilko reiterated the limits of judicial review of arbitral awards: "interpretations of the law by the arbitrators in contrast to manifest disregard are not subject . . . to judicial review for error in interpretation.”127 The Court thus suggested that awards demonstrating "manifest disregard" - whatever that might entail—could be vacated. The Court recently reaffirmed the manifest disregard test, again in dicta, in First Options of Chicago, Inc. v. Kaplan. ${ }^{128}$

The lower courts have been highly inconsistent in applying the manifest disregard standard. ${ }^{129}$ Most have applied the test to questions of law. That is, they vacate awards upon a showing that the arbitrator acted in manifest disregard of the law. ${ }^{130}$ More specifically, most of these courts require evidence of a conscious decision by the arbitrator to decide contrary to a clearly applicable governing rule. The Second Circuit has explained:

The error must have been obvious and capable of being readily and instantly perceived by the average person qualified to serve as an arbitrator. Moreover, the term "disregard" implies that the arbitrator appreciates the existence of a clearly governing legal principle but decides to ignore or pay no attention to it. . . . The governing law alleged to have been ignored by the arbitrators must be well defined, explicit, and clearly applicable.

Some courts have invoked standards of review focusing not on the arbitrator's conscious failure to follow governing legal rules, but on the rationality of the award. For example, in Swift Industries, Inc. $v$.

that the manifest disregard test does not exist; it simply concluded that the test is functionally equivalent to the public policy test as elaborated in Eastern Associated Coal. Id. at 580 .

127 Wilko, 346 U.S. at 436-37 (emphasis added).

128514 U.S. 938, 942 (1995).

129 See Watts, 248 F.3d at 579-80 (discussing inconsistencies in case law and referring to Supreme Court application of the manifest disregard standard as “opaque”).

130 See Norman S. Poser, Judicial Review of Arbitration Awards: Manifest Disregard of the Law, 64 BROOK. L. REV. 471, 471-72 (1998). Some courts have gone even further and suggested that manifest disregard might be grounds for vacating an award demonstrating a clear factual error. See Halligan v. Piper Jaffray, Inc., 148 F.3d 197, 204 (2d Cir. 1998).

131 Merrill Lynch, Pierce, Fenner \& Smith, Inc. v. Bobker, 808 F.2d 930, 933-34 (2d Cir. 1986) (citations omitted). See also Merrill Lynch, Pierce, Fenner \& Smith, Inc. v. Jaros, 70 F.3d 418, 421 (6th Cir. 1995) (“[A]n arbitration panel does not act in manifest disregard of the law unless (1) the applicable legal principle is clearly defined and not subject to reasonable debate; and (2) the arbitrators refused to heed that legal principle.”). 
Botany Industries, Inc., ${ }^{132}$ the Third Circuit vacated an award because of its "complete lack of rationality" after concluding that the agreement could not be read to allow for the type of award the arbitrator granted. ${ }^{133}$ In that form, the irrationality test looks much like the "essence" test from Enterprise Wheel. ${ }^{134}$

Courts have occasionally discussed rationality in the context of alleged errors of law, but they have refrained from vacating awards on that basis. ${ }^{135}$ At most, they have sometimes remanded for additional explanation where an award appears irrational on its face and lacks any stated rationale. ${ }^{136}$ In Sargent v. Paine Webber, Jackson \& Curtis, Inc., ${ }^{137}$ for example, the district court for the District of Columbia concluded that "a court should not attempt to enforce an award that is ambiguous, indefinite or irrational." ${ }^{138}$ The court went on to state that "[a]lthough a court is precluded from overturning errors in factual determinations, 'nevertheless, if an examination of the record before the arbitrator reveals no support whatever for his determinations, his award must be vacated." "'39 The court remanded, directing the arbitrator to explain an award that granted the claimants less than twenty percent of their apparent losses. ${ }^{140}$

\footnotetext{
132466 F.2d 1125 (3d Cir. 1972).

133 Id. at 1135. See also Lentine v. Fundaro, 278 N.E.2d 633, 634 (N.Y. 1972) (holding that "[s]ave for 'complete irrationality', arbitrators are free to fashion the applicable rules and determine the facts of a dispute before them without their award being subject to judicial revision.”).

134 See Jenkins v. Prudential-Bache Sec., Inc., 847 F.2d 631, 634 (10th Cir. 1988) (treating the "completely irrational" test and the "essence" test as equivalent); Indus. Mut. Ass’n v. Amalgamated Workers, Local Union No. 383, 725 F.2d 406, 412 (6th Cir. 1984) (conflating the two tests); Detroit Coil Co. v. Int'l Ass'n of Machinists \& Aerospace Workers, Lodge \#82, 594 F.2d 575, 579 (6th Cir. 1979) (requiring that the arbitrator's award draws its "essence" from the collective bargaining agreement and that it is "derived in some rational way from the collective bargaining agreement”).

135 See, e.g., Bettencourt v. Boston Edison Co., 560 F.2d 1045, 1049 (1st Cir. 1977) (finding no "manifest error of law" sufficient to warrant vacating award).

136 See Kenneth R. Davis, When Ignorance of the Law Is No Excuse: Judicial Review of Arbitration Awards, 45 BUFF. L. REV. 49, 105-06 (1997).

137674 F. Supp. 920 (D.D.C. 1987).

138 Id. at 922.

${ }^{139}$ Id. (quoting NF\&M Corp. v. United Steelworkers, 524 F.2d 756, 760 (3d Cir. 1975)).

140 Id. at 921.
} 


\section{Current Trends and Conclusions}

Lower courts seem to be hearing an increasing number of challenges to arbitral awards. In particular, challenges asserting that awards are in manifest disregard of the law have increased markedly since the Supreme Court reaffirmed that test in its 1995 decision in First Options. In the five years from 1990 through 1994, an average of just under seven reported federal district court decisions per year discussed manifest disregard as a ground for vacating an arbitral award. $^{141}$ In the five years from 2000 through 2004, that number more than doubled to almost seventeen reported district court decisions per year. ${ }^{142}$

Although the number of cases raising manifest disregard seems to be increasing, it remains extremely rare for courts to vacate awards on that ground. Of the reported cases in the periods from 1990 to 1994 and 2000 to 2004, not a single district court vacated an award on

141 These figures were derived from Westlaw searches in the federal district courts database. Bankruptcy courts are included. I searched for cases covered by West's key number for judicial review of arbitral awards in which the term "manifest disregard" appears. In some of the cases, the courts simply referred to manifest disregard as one possible basis for vacating an award, even though no party relied on manifest disregard to challenge the award in question.

142 Based on Westlaw searches of the federal district court database the number of reported district court decisions discussing "manifest disregard" as a ground for judicial review of arbitral awards for each year from 1990 through 2004 are as follows:

$\begin{array}{lc}\text { YEAR } & \text { NUMBER OF DECISIONS } \\ 2004 & 16 \\ 2003 & 21 \\ 2002 & 16 \\ 2001 & 15 \\ 2000 & 15 \\ 1999 & 15 \\ 1998 & 18 \\ 1997 & 13 \\ 1996 & 9 \\ 1995 & 8 \\ 1994 & 7 \\ 1993 & 8 \\ 1992 & 6 \\ 1991 & 6 \\ 1990 & 7\end{array}$


manifest disregard grounds. ${ }^{143}$ Two courts vacated awards on other grounds tied to arbitrator irrationality, but both were reversed on appeal. ${ }^{144}$ Several other courts remanded cases to the arbitrators for clarification. ${ }^{145}$

A handful of circuit courts have vacated awards on manifest disregard grounds, ${ }^{146}$ sometimes affirming unpublished district court decisions. ${ }^{147}$ Undoubtedly a number of other district courts also vacated awards without publishing opinions. But it seems clear that only a small fraction of challenges to awards based on manifest disregard and related standards succeed, and few even receive meaningful review.

143 However, courts vacated awards on other grounds. See Ass'n of Flight Attendants v. Aloha Airlines, Inc., 158 F. Supp. 2d 1200, 1206 (D. Haw. 2001) (determining that award did not draw its essence from the contract because it was issued by only one member of the panel of arbitrators); NCR Corp. v. CBS Liquor Control, Inc., 874 F. Supp. 168, 175 (S.D. Ohio 1993) (finding that arbitrator exceeded powers); In re Arbitration Between Household Mfg., Inc. \& Kowin Dev. Corp., 822 F. Supp. 505, 510 (N.D. Ill. 1993) (finding that arbitrator awarded same amount of damages to single party twice); A.G. Edwards \& Sons, Inc. v. McCullough, 764 F. Supp. 1365, 1371 (D. Ariz. 1991) (determining that party procured award by "undue means" by making blatantly false statements of law); Kerr-McGee Refining Corp. v. Triumph Tankers Ltd., 740 F. Supp. 288, 291 (S.D.N.Y. 1990) (holding that arbitrators exceeded their power).

144 See Brabham v. A.G. Edwards \& Sons, Inc., 265 F. Supp. 2d 720, 725-26 (S.D. Miss. 2003) (vacating damage award by arbitrator because its calculation was "arbitrary and capricious”), rev'd, Brabham v. A.G. Edwards \& Sons, Inc., 376 F.3d 377 (5th Cir. 2004); Wonderland Greyhound Park, Inc. v. Autotote Sys., Inc., 144 F. Supp. 2d 25, 29 (D. Mass. 2001) (vacating after finding no "tenable ground" for the acceleration of an award), vacated with an order to enforce the arbitral award, Wonderland Greyhound Park, Inc. v. Autotote Sys., Inc., 274 F.3d 34 (1st Cir. 2001).

145 See Lummus Global Amazonas, S.A. v. Aguaytia Energy del Peru S.R. Ltda., 256 F. Supp. 2d 594, 650 (S.D. Tex. 2002); Weinberg v. Silber, 140 F. Supp. 2d 712, 724 (N.D. Tex. 2001); Collins \& Aikman Floor Coverings Corp. v. Froehlich, 736 F. Supp. 480, 48788 (S.D.N.Y. 1990).

146 See Hardy v. Walsh Manning Sec., L.L.C., 341 F.3d 126, 130 (2d Cir. 2003) (finding that "since 1960 we have vacated some part or all of an arbitral award for manifest disregard in . . . four out of at least 48 cases where we applied the standard") (quoting Duferco Int'l Steel Trading v. T. Klaveness Shipping A/S, 333 F.3d 383, 389 (2d Cir. 2003) (alteration in original).

147 See Nationwide Mut. Ins. Co. v. Home Ins. Co., 330 F.3d 843, 845 (6th Cir. 2003); Gas Aggregation Servs., Inc. v. Howard Avista Energy, L.L.C., 319 F.3d 1060, 1069 (8th Cir. 2003). 
II

\section{FROM ADJUDICATION TO CONTRACT: TWO MODELS OF ARBITRATION}

As arbitration has become an increasingly pervasive feature of the dispute resolution landscape, two theories, or models, of arbitration have emerged. ${ }^{148}$ These models, which I will refer to as the adjudicatory model and the contractarian model, inform the way courts perceive and respond to arbitration. I will sketch each of the models in order to show how the contractarian model seems to better account for modern judicial attitudes toward arbitration.

\section{A. The Adjudicatory Model}

There is a natural tendency, particularly among courts, to conceptualize arbitration as simply a private version of court adjudication. The Supreme Court, in an 1855 decision, expressly equated arbitration with private adjudication, declaring that "[a]rbitrators are judges chosen by the parties to decide the matters submitted to them, finally and without appeal."149 Modern legal scholars often discuss arbitration in those terms as well. In their seminal article Adjudication as a Private Good, William Landes and Richard Posner discuss arbitration as the primary modern example of private adjudication. ${ }^{150}$ They note that "[a]rbitrators typically apply the same rules as courts deciding similar questions" and go on to compare arbitration to adjudication as a way of assessing the efficiency of adjudication. ${ }^{51}$ It seems not to occur to them to understand arbitration as anything other than a substitute for formal, public adjudication.

The distinctive feature of court adjudication is its focus on legal rights and obligations. Courts find facts and then apply rules of law to determine those rights and obligations. An observer who

\footnotetext{
148 The first scholarly discussion of the two models of arbitration appeared in 1927, shortly after the passage of the Federal Arbitration Act opened the door to broad enforcement of arbitration agreements. See Nathan Isaacs, Two Views of Commercial Arbitration, 40 HARV. L. REV. 929 (1927). Lon Fuller suggested a similar dichotomy between arbitrators who act as private adjudicators and those who see themselves as conciliators unrestrained by procedural limitations. See Lon L. Fuller, Collective Bargaining and the Arbitrator, 1963 WIS. L. REV. 3, 3-4.

149 Burchell v. Marsh, 58 U.S. 344, 349 (1855).

150 See generally Landes \& Posner, supra note 30 (arguing that private adjudication can provide a beneficial model for public adjudication).

151 Id. at 249-53.
} 
understands arbitration as a substitute for formal adjudication will expect the arbitrator to act like a judge in finding facts and applying rules of law. This is an approach that the Supreme Court adopted during the early years of the FAA. ${ }^{152}$ Wilko is a good example. ${ }^{153}$

The Court in Wilko refused to enforce an agreement to arbitrate claims under the Securities Act of $1933 .^{154}$ The Court dismissed arguments that an arbitrator could protect legal rights with the same competence as a court, but it did not take issue with the basic characterization of the arbitration process as a substitute for trial. ${ }^{155}$ It assumed that the arbitrators would function essentially as lower courts and simply rejected arbitration as an inadequate substitute. ${ }^{156}$ Justice Frankfurter, writing in dissent, made this understanding explicit, though he reached a different outcome as to the case's arbitrability. ${ }^{157}$ Concluding that arbitration could effectively vindicate rights under the Securities Act, he described the FAA as impelled by "the advantages of providing a speedier, more economical and more effective enforcement of rights by way of arbitration than can be had by the tortuous course of litigation.”158

When courts like the one in Wilko look at an arbitration, they see one or more aggrieved claimants demanding a decision as to which party is in the right and which is in the wrong. They see facts to be determined and rules to be applied. Their fundamental concern is with the arbitrator's capacity to vindicate legal rights in a manner commensurate with a court's.

\section{B. The Contractarian Model}

As natural as the private adjudication model might seem, it is not the only way to conceptualize arbitration. Arbitration may also be understood as a species of contract. In the contractarian model, the arbitrator is not an adjudicator tasked with finding facts and applying generally applicable legal rules. The arbitrator is instead the parties'

\footnotetext{
152 See supra notes 30-33 and accompanying text.

153 Wilko v. Swan, 346 U.S. 427 (1953), overruled by Rodriguez de Quijas v. Shearson/American Express, Inc., 490 U.S. 477 (1989).

154 Id. at 436-37.

155 See id. at 435-36.

156 See id. at 437-38 (discussing and rejecting arbitration as an alternative "forum” for resolving the parties' dispute).

157 Id. at 440 (Frankfurter, J., dissenting).

158 Id. at $439-40$.
} 
agent, tasked with interpreting their agreement once they reach an impasse. The prominent labor scholar Theodore St. Antoine described the contractarian model in these terms:

Put most simply, the arbitrator is the parties' officially designated "reader" of the contract. He (or she) is their joint alter ego for the purpose of striking whatever supplementary bargain is necessary to handle the anticipated unanticipated omissions of the initial agreement. Thus, a "misinterpretation" or "gross mistake" by the arbitrator becomes a contradiction in terms. In the absence of fraud or an overreaching of authority on the part of the arbitrator, he is speaking for the parties, and his award is their contract. ... In sum, the arbitrator's award should be treated as though it were a written stipulation by the parties setting forth their own definitive construction of the labor contract.

Again, in this model, the arbitrator does not act as a substitute judge. The arbitrator is a surrogate for the parties, supplying the terms left out of their initial agreement. The arbitrator's focus is on giving efficacy to the parties' agreement rather than on deciding who is right and who is wrong.

The contractarian model has inspired arbitration's proponents for many years. Its first scholarly exegesis appeared in a 1927 article in the Harvard Law Review. ${ }^{160}$ The author contrasted the "legalistic view" of arbitration, which focuses on the arbitrator's adjudicative role, with the "realistic view," which understands the arbitrator as modifying the parties' substantive relationship. ${ }^{161}$ He pointed out the tendency of businessmen to adopt the realistic view instead of the legalistic view favored by the courts. ${ }^{162}$ Consistent with that theme, Herbert Harley, then Secretary of the American Judicature Society, emphasized commercial arbitration's focus on the relationship over the law in a 1916 Bulletin of the Society. He noted that "[i]n the law the rendering of exact justice in the matter presented is a final aim. But in business the settlement of a given dispute is not the most important thing. The big thing is the relationship between the parties." 163

This understanding of arbitration's role seems to have animated the FAA. The FAA was the product of the ABA's Committee on

159 Theodore J. St. Antoine, Judicial Review of Labor Arbitration Awards: A Second Look at Enterprise Wheel and its Progeny, 75 MICH. L. REV. 1137, 1140 (1977).

160 Isaacs, supra note 148.

161 Id. at 929.

162 Id. at 938.

163 Julius HENRY COHEN, COMMERCIAL ARBITRATION AND THE LAW 18 (1918). 
Commerce, Trade, and Commercial Law. ${ }^{164}$ It was drafted by lawyers for businessmen who intended arbitration to be used to resolve disputes among businessmen. Their focus was not on the adjudication of substantive rights, but on the resolution of day-to-day disputes that arise in the course of a commercial relationship. The principal drafter and proponent, Julius Henry Cohen, described arbitration under the FAA in these terms:

Not all questions arising out of contracts ought to be arbitrated. It is a remedy peculiarly suited to the disposition of the ordinary disputes between merchants as to questions of fact-quantity, quality, time of delivery, compliance with terms of payment, excuses for non-performance, and the like. It has a place also in the determination of the simpler questions of law-the questions of law which arise out of these daily relations between merchants as to the passage of title, the existence of warranties, or the questions of law which are complementary to the questions of fact which we have just mentioned. It is not the proper method for deciding points of law of major importance involving constitutional questions or policy in the application of statutes.

Cohen saw arbitration as a vehicle for resolving the routine disputes that arise between commercial trading partners as they perform their contractual obligations. He never contemplated that arbitration would take the place of adjudication in the determination of substantive legal rights. Although Cohen never expressly discussed these models, his understanding of arbitration seems much closer to the contractarian model than to the adjudicatory model. His understanding is also consistent with the narrow grounds of judicial review allowed by the FAA. If arbitrators are not acting in an adjudicatory capacity, then there is no need for courts to review their work in search of errors of law. ${ }^{166}$

The Supreme Court implicitly adopted the contractarian model of arbitration, at least for labor cases, in United Steelworkers $v$. Enterprise Wheel \& Car Corp. ${ }^{167}$ Enterprise Wheel involved the arbitration of a grievance under a collective bargaining agreement. ${ }^{168}$

\footnotetext{
164 See IAN R. MACNEIL, AMERICAN ARBITRATION LAW: REFORMATION, NATIONALIZATION, INTERNATIONALIZATION 41 (1992).

165 Julius Henry Cohen \& Kenneth Dayton, The New Federal Arbitration Law, 12 VA. L. REV. 265, 281 (1926).

166 See Ware, supra note 13, at 729-31. "The entire FAA embodies a strongly contractual approach to arbitration law.” Id. at 729.

167363 U.S. 593 (1960).

168 Id. at 595.
} 
In the arbitration, the union represented several employees who had been fired for walking off the job. ${ }^{169}$ The arbitrator reinstated them and awarded back pay, even though the collective bargaining agreement had expired prior to the issuance of the award. ${ }^{170}$ The employer refused to comply with the award, arguing that it was unenforceable because the employees were no longer covered by the collective bargaining agreement. ${ }^{171}$ The union sought enforcement in the district court, which refused to upset the arbitrator's award. ${ }^{172}$ The court of appeals, however, agreed with the employer that the arbitrator could not grant relief for the period after the expiration of the collective bargaining agreement and vacated that portion of the award. ${ }^{173}$

The Supreme Court reversed on that issue, holding that the court had no power to review the merits of the award. Its reasoning on that relatively uncontroversial point is significant:

The collective bargaining agreement could have provided that if any of the employees were wrongfully discharged, the remedy would be reinstatement and back pay up to the date they were returned to work. Respondent's major argument seems to be that by applying correct principles of law to the interpretation of the collective bargaining agreement it can be determined that the agreement did not so provide, and that therefore the arbitrator's decision was not based upon the contract. The acceptance of this view would require courts, even under the standard arbitration clause, to review the merits of every construction of the contract. . . . [T]he question of interpretation of the collective bargaining agreement is a question for the arbitrator. It is the arbitrator's construction which was bargained for; and so far as the arbitrator's decision concerns construction of the contract, the courts have no business overruling him because their interpretation of the contract is different from his.

The Court treated the arbitrated issue not as a dispute calling for some form of adjudicatory decision, but as an aspect of the parties' ongoing contractual relationship. In keeping with the contractarian model, the Court focused on the terms of the agreement rather than on the determination of substantive legal rights.

$$
\begin{aligned}
& 169 \text { Id. } \\
& 170 \text { Id. } \\
& 171 \text { See id. } \\
& 172 \text { Id. } \\
& 173 \text { Id. at 595-96. } \\
& 174 \text { Id. at 598-99. }
\end{aligned}
$$


Other recent cases, both in the Supreme Court and the circuit courts, seem also to have employed the contractarian model. In Eastern Associated Coal, ${ }^{175}$ the Supreme Court refused to vacate an award reinstating a truck driver who twice tested positive for marijuana. ${ }^{176}$ The Court noted that the parties had " "bargained for' the 'arbitrator's construction' of their agreement” and concluded that it had to "treat the arbitrator's award as if it represented an agreement between [the employer] and the union as to the proper meaning" of the contract's terms. ${ }^{177}$ The Court was echoing Judge Easterbrook, who, in a 1986 opinion emphasizing the limits of judicial review of arbitral awards, argued that "the [FAA] restricts the court to ascertaining that the arbitrator was a faithful agent of the contracting parties." 178

These decisions all addressed labor disputes, and indeed the contractarian model seems most obviously applicable in labor and commercial cases. ${ }^{179}$ Moreover, while cases like Wilko invoke the adjudicatory model where arbitration of statutory rights is at issue, this approach to judicial review has been repudiated. ${ }^{180}$ The approach courts take to judicial review of arbitral awards today-not just in the labor or commercial contexts but in all cases-indicates an attitude toward arbitration that is more consistent with the contractarian model than the adjudicatory model. ${ }^{181}$ The deference courts pay to arbitrators goes far beyond the deference they pay to lower courts or even to administrative bodies. Courts flatly say that

\footnotetext{
175 E. Associated Coal Corp. v. UMW Dist. 17, 531 U.S. 57 (2000).

176 Id. at $60-61$.

177 Id. at 61-62 (quoting United Steelworkers v. Enterprise Wheel \& Car Corp., 363 U.S. 593, 599 (1960)).

178 E.I. DuPont de Nemours \& Co. v. Grasselli Employees Ind. Ass’n of E. Chicago, Inc., 790 F.2d 611, 619 (7th Cir. 1986) (Easterbrook, J., concurring).

179 In the Steelworkers trilogy, the Supreme Court distinguished between commercial arbitration, which it characterized as a substitute for litigation, and labor arbitration, which it characterized as a substitute for labor strife. United Steelworkers v. Warrior \& Gulf Navigation Co., 363 U.S. 574, 578 (1960).

180 Rodriguez de Quijas v. Shearson/American Express, Inc., 490 U.S. 477, 485 (1989) (overruling Wilko v. Swan, 346 U.S. 427 (1953)).

181 Stephen L. Hayford, Unification of the Law of Labor Arbitration and Commercial Arbitration: An Idea Whose Time Has Come, 52 BAYLOR L. REV. 781, 863 (2000) (“The Supreme Court now views the FAA as establishing a preemptive body of federal law strongly favoring the enforcement of contractual agreements to arbitrate. It sees commercial arbitration 'strictly as a matter of contract' and considers the role of the courts to be one of simply giving effect to the intent of parties who agree to arbitrate future disputes.”) (citation omitted).
} 
they will not vacate an arbitral award for legal or factual error even if the error is gross. ${ }^{182}$ Today, in practice, arbitrators in all cases are treated as agents of the parties rather than as deputized semipublic referees.

The conceptual shift toward a contractarian model of arbitration is consistent with the trend toward what Judith Resnik has called "Contract Procedure." ${ }^{183}$ Judges increasingly see their role as promoting and enforcing private contracts for the resolution of disputes rather than as ensuring that litigants receive due process. The move toward Contract Procedure appears in the encouragement of judicial participation in settlement negotiations, ${ }^{184}$ the growth of judicially sanctioned alternative dispute resolution, ${ }^{185}$ and the devolution of dispute resolution from courts to agencies. ${ }^{186}$ Its consequence is a new role for judges, whose job is no longer to decide cases but to manage a party-driven and largely unstructured bargaining process. The contractarian model of arbitration is part and parcel of this broader shift. Judges operating under the contractarian model do not see the arbitrator as a surrogate judge who must apply rules guaranteeing due process as a judge would. Instead, the arbitrator is the parties' representative who must be given free rein to formulate an effective pragmatic resolution.

Neither the adjudicatory nor the contractarian model is "correct," and I do not mean to suggest that courts presented with the choice would invariably subscribe to the contractarian model instead of the adjudicatory model. The models simply provide alternative ways of thinking about arbitration; the same court may employ one model in one case and the other model in a different case. My contention is that the contractarian model better explains the standard of review contained in the FAA and the usual behaviors of judges reviewing arbitral awards. It also meshes better with larger trends in adjudicative procedure. For these reasons, it provides a useful perspective from which to analyze and evaluate the relationship between arbitration and law.

\footnotetext{
182 See United Paperworkers Int’l Union v. Misco, Inc., 484 U.S. 29, 36-38 (1987).

183 Judith Resnik, Procedure as Contract, 80 NOTRE DAME L. REV. 593, 598 (2005) ("While Procedure was once concerned about generating secondary rules by which to render judgment, today the task is to shape secondary rules for interpreting parties' agreements ....").

184 See id. at 611-17.

185 See id. at $619-21$.

186 See id. at 621-22.
} 
III

\section{THE LAW OF CONTRACT AND THE WAIVER OF LEGAL RIGHTS THROUGH ARBITRATION}

Courts have the power to validate or invalidate arbitration and other ADR processes as alternatives both to formal adjudication and to law. When courts enforce agreements to arbitrate, at a minimum they signal their acceptance of arbitration as an alternative to formal adjudicative process.

Common-law courts refused to enforce arbitration agreements. ${ }^{187}$ They saw formal adjudicative process as such an essential right that they would not allow a party to prospectively waive the right to formal adjudication. Today, courts are under explicit directions from the Supreme Court to enforce arbitration agreements. The Supreme Court no longer sees the waiver of formal adjudicative process as the waiver of a fundamental right, and it has validated arbitration as an alternative in that sense. ${ }^{188}$ As a consequence, the Supreme Court has allowed arbitration to expand into every corner of the law. As a practical matter, any dispute is arbitrableclaim is potentially subject to binding contractual arbitration, regardless of the legal rights and legal rules the disputeit implicates.

That raises the question of the extent to which arbitration can serve as an alternative to law. The Supreme Court has said unequivocally that statutory rules, especially those that create substantive rights, do apply in arbitration. In Mitsubishi Motors Corp. v. Soler ChryslerPlymouth, Inc. ${ }^{189}$ the case that opened the floodgates to arbitration, the Supreme Court expressly declared that parties do not forfeit statutory rights by agreeing to arbitrate: "By agreeing to arbitrate a statutory claim, a party does not forgo the substantive rights afforded by the statute; it only submits to their resolution in an arbitral, rather than a judicial, forum." ${ }^{190}$ The Mitsubishi Court held antitrust claims

187 See Donald E. Johnson, Has Allied-Bruce Terminix Cos. v. Dobson Exterminated Alabama's Anti-Arbitration Rule?, 47 ALA. L. REV. 577, 579-80 (1996) for a brief history of the common-law view of arbitration.

188 As I suggested above, with respect to arbitration as an alternative to legal process, the only real limitation is cost. A stronger party may not condition access to arbitration for a weaker party on the expenditure of costs that would be significantly greater than required for court adjudication. See Green Tree Fin. Corp.-Ala. v. Randolph, 531 U.S. 79, 90 (2000). Beyond that, however, the process options are virtually unlimited.

189473 U.S. 614 (1985).

190 Id. at 628. 
arbitrable. ${ }^{191}$ The Court later reiterated that principle in Rodriguez de Quijas, ${ }^{192}$ McMahon, ${ }^{193}$ and Gilmer, ${ }^{194}$ cases upholding arbitration of statutory claims under RICO, the federal securities laws, and the ADEA. In theory, then, parties have a presumptive right to the enforcement of statutory rules in arbitration. An arbitrator does not have the prerogative to disregard the statutory rights and liabilities that a judge would be obligated to take into account.

In practice, however, the right to the application of statutory rights means little because of the deference courts give to arbitral awards. ${ }^{195}$ For instance, an award that would result in an illegal restraint of trade would be unenforceable under the narrow public policy ground enunciated in Eastern Associated Coal because it would direct the parties to violate the law. That is an easy case because the law contravened by the award exists to protect the public. Where the statutory rules at issue exist primarily to protect individual participants, however, courts almost never vacate even when an error of law is obvious. For example, in DiRussa v. Dean Witter Reynolds, Inc., ${ }^{196}$ the arbitrators awarded plaintiff compensatory damages under the ADEA but refused to grant him attorneys' fees even though the ADEA expressly mandates the award of attorneys' fees to a successful plaintiff. ${ }^{197}$ The Second Circuit concluded that because the arbitrators did not know that attorneys' fees were statutorily required, there was no manifest disregard of the law. ${ }^{198}$ It enforced the award. ${ }^{199}$

DiRussa is an unusual case in two respects. First, the arbitrators disclosed their failure to follow the law on the face of the award. ${ }^{200}$ Most arbitral awards do not contain explanations at all, and the ones that do typically do not make the errors appear so obvious. For that reason, it is often impossible for a court to evaluate an award for legal error even if the court is so inclined. Second, courts operate within a legal framework that discourages them from finding legal error, so

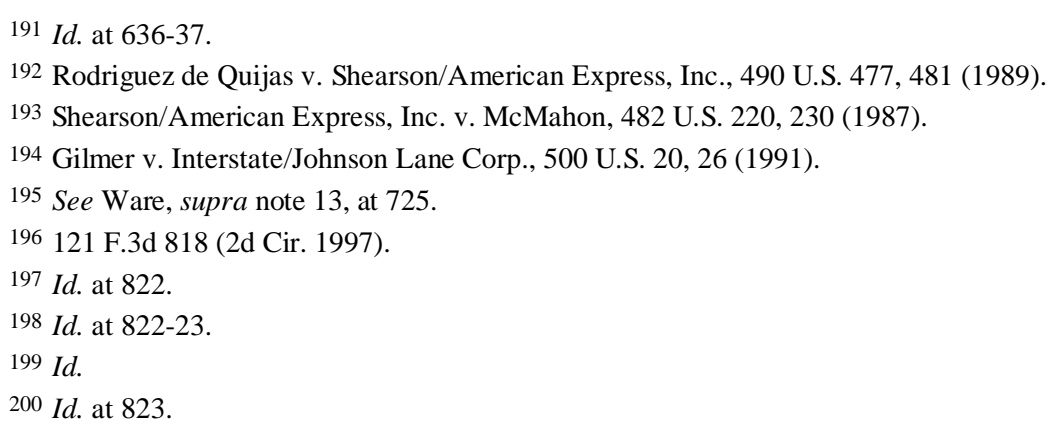


they tend to describe awards in terms that make the award sound rational. $^{201}$ This tendency makes it very difficult to identify the reported decisions in which arbitrators made significant errors in applying legal rules.

It is simply impossible to know the extent to which arbitrators misapply or fail to apply governing statutory rules in the great run of cases that never reach a judge or that do not contain errors made as apparent as the error in DiRussa. ${ }^{202}$ But we can assume that arbitrators frequently apply statutes in ways that appellate courts would conclude constitute reversible error. The available empirical studies show that many arbitrators consciously choose to ignore legal rules at least some of the time. ${ }^{203}$ And we can assume based on the reversal rates for trial courts that those arbitrators who attempt to apply the law make relatively frequent mistakes.

Take discrimination as an example. While comprehensive data on reversal rates is not readily available, it appears that between twentyfive and thirty percent of appeals in civil rights cases result in a reversal, a remand, or both. ${ }^{204}$ Even if many of these reversals are for procedural errors, trial judges must be making significant numbers of legal errors in applying federal civil rights statutes. Arbitrators almost certainly are not better at applying statutes than trial judges. They must make reversible mistakes at least as often. ${ }^{205}$

Given current standards of arbitral review, there is simply no assurance that statutory rules will be applied at all, much less applied in the way a judge would apply them. As a practical matter, arbitration can be a vehicle for avoiding the law. This is true whether the parties have equal bargaining power and knowingly choose to

201 See, e.g., Am. Life Ins. Co. v. Parra, 269 F. Supp. 2d 519, 526 (D. Del. 2003). The arbitrators in Parra refused to award prejudgment interest, apparently in contravention of governing Delaware law. Id. The court upheld the award, taking pains to paint the award as legally defensible: "[C]redible arguments can be made that, under both Federal and Delaware law, prejudgment interest is not mandatory in all circumstances and the arbitrators could have viewed themselves, and apparently did view themselves, as free to exercise discretion in that regard.” Id.

202 A thorough empirical study might be able to determine this, but such a study is probably impossible given the confidentiality constraints that typically apply in arbitration.

203 See Ware, supra note 13, at 719-20 (summarizing studies).

204 These figures were generated through Westlaw searches of federal circuit court appeals raising issues under Title VII and Title VIII of the Civil Rights Act and under the Americans with Disabilities Act for the ten years from 1995 through 2005.

205 See, e.g., Bowles Fin. Group, Inc. v. Stifel, Nicolaus \& Co., 22 F.3d 1010, 1011 (10th Cir. 1994) ("Arbitration provides neither the procedural protections nor the assurance of the proper application of substantive law offered by the judicial system.”). 
forgo legal rights or whether one party agrees to a contract of adhesion with no real understanding of the rights he or she may be sacrificing. In at least some cases, this use of arbitration to avoid law amounts to a prospective waiver of legal rights that basic rules of contract law proscribe.

\section{A. The Prospective Waiver of Legal Rights Under Contract Law}

As the Supreme Court first began to free arbitration from the boundaries of collective bargaining agreements and commercial disputes, it expressed concern about the possible waiver of important legal rights. That concern appears most prominently in Alexander $v$. Gardner-Denver Co., ${ }^{206}$ in which the Court held that the submission of an employment discrimination claim to arbitration did not cut off the right to sue under Title VII. ${ }^{207}$ The Court concluded that "an employee's rights under Title VII are not susceptible of [sic] prospective waiver." 208

Since Gardner-Denver, the Court has changed its stance. It now sees enforcing agreement terms as part of its job and the job of courts in general. It has taken this to mean enforcing awards under virtually all circumstances as long as the arbitrator did not stray from the "essence" of the contract. The only limitation the Court has imposed is the very narrow public policy ground that seems to apply only when the award would require a party to break the law.

This approach is consistent with the Court's adoption of a contractarian model of arbitration. The Court equates enforcing an agreement with enforcing an award because it sees the arbitrator as the parties' agent for interpreting the agreement. Under this model, the arbitrator's award is understood to be equivalent to a contract term agreed upon by the parties ex ante. The plaintiff in DiRussa, for example, can be understood as having agreed to waive his statutorily prescribed right to attorneys' fees in the event he proved that his employer discriminated against him. By enforcing the award, the Court upheld that "bargain" despite the Supreme Court's assurances that statutory rights should be protected in arbitration. As a practical

\footnotetext{
206415 U.S. 36 (1974)

207 Id. at 56-57.

208 Id. at 51-52.
} 
matter, the Court allowed the parties to avoid the application of the law by contracting around it. ${ }^{209}$

The lynchpin of this model is the parties' assent. Courts seem untroubled by the possibility that an arbitrator might misapply or fail to apply the law because that is what the parties agreed to. ${ }^{210}$ The problem with this approach is that it assumes far greater liberty of contract than actually exists. Parties cannot contract to break the law. More importantly for arbitration purposes, though, is that parties often cannot contract to waive their own legal rights. The law governing such "exculpatory contracts" has important ramifications for the law of arbitration that the courts have failed to recognize. ${ }^{211}$ These ramifications call into question the validity of arbitration as an alternative to law.

Contractual agreements to shift risk go by many different labels, including waiver, release, and indemnification. ${ }^{212}$ I use the term exculpatory contract to cover any situation in which one party to a contract agrees to relieve another party of liability for harms resulting from the conduct of the latter. Exculpatory contracts, in this sense, typically take the form of releases or waivers of rights or defenses.

Traditionally, exculpatory contracts have been disfavored, ${ }^{213}$ and in certain situations they are per se unenforceable. The Restatement (Second) of Contracts states flatly that "[a] term exempting a party from tort liability for harm caused intentionally or recklessly is unenforceable on grounds of public policy."214 The rule is not

209 See Ware, supra note 13, at 726. "When courts confirm arbitration awards that make errors of law, parties lose the substantive rights that would have been vindicated by an application of the law.” Id.

210 See Edward Brunet, The Core Values of Arbitration, in BRUNET ET AL., supra note 22, at 3.

211 It is important to note that the FAA does not preempt state law on exculpatory contracts. The FAA preempts state law applying specifically to arbitration, but it does not preempt generally applicable state contract law. See Perry v. Thomas, 482 U.S. 483, 492 (1987). "[S]tate law, whether of legislative or judicial origin, is applicable if that law arose to govern issues concerning the validity, revocability, and enforceability of contracts generally. A state-law principle that takes its meaning precisely from the fact that a contract to arbitrate is at issue does not comport with this requirement of [9 U.S.C.] § 2.” Id. at 493 n.9.

212 See Dresser Indus., Inc. v. Page Petroleum, Inc., 853 S.W.2d 505, 508 (Tex. 1993), for helpful definitions of waiver, release, and indemnification.

213 See, e.g., Heil Valley Ranch, Inc. v. Simkin, 784 P.2d 781, 783 (Colo. 1989) ("Agreements attempting to exculpate a party from that party's own negligence have long been disfavored.”) (citing Jones v. Walt Disney World Co., 409 F. Supp. 526, 528 (W.D.N.Y. 1976); Harris v. Walker, 519 N.E.2d 917, 919 (Ill. 1988)).

214 RESTATEMENT (SECOND) OF CONTRACTS § 195(1) (1981). 
limited to physical harms, so it would apply to agreements purporting to absolve a party from such intentional harms as discrimination and fraud. ${ }^{215}$ Exculpatory contracts are also unenforceable where they would relieve a seller from strict product liability. ${ }^{216}$

Exculpatory contracts that relieve a party from liability for its own negligence are enforceable within limits. One of those limits applies in the employment arena: a contract may not relieve an employer from liability for its negligence that injures an employee. ${ }^{217}$ Another limit applies to common carriers, who may not exempt themselves from liability for their own negligence toward members of the public whom they serve. ${ }^{218}$

Beyond those situations, courts typically evaluate a number of factors in deciding whether to enforce exculpatory contracts that relieve a party from its unintentional torts. For example, the Colorado Supreme Court has identified four factors to consider: “(1) the existence of a duty to the public; (2) the nature of the service performed; (3) whether the contract was fairly entered into; and (4) whether the intention of the parties is expressed in clear and unambiguous language.”219 Other courts list different factors, but most seem to be looking for the same basic things. They are reluctant to enforce exculpatory agreements where the party relieved of liability is performing a public service, where there is a serious disparity in bargaining power, or where the exculpatory term is ambiguous or hidden.

The most important case addressing exculpatory contracts relating to public services is Tunkl v. Regents of the University of California. ${ }^{20}$ In Tunkl, the UCLA Medical Center required a patient to sign a release upon admission that relieved the hospital "from any and all liability for the negligent or wrongful acts or omissions of its

215 See 15 GRACE MCLANE GIESEL, CORBIN ON CONTRACTS: CONTRACTS CONTRARY TO PUBLIC POLICY § 88.8 (2003).

216 See RESTATEMENT (SECOND) OF CONTRACTS, supra note 214, § $195 \mathrm{cmt}$. c. See generally RESTATEMENT (THIRD) OF TORTS: PRODUCTS LIABILITY $§ 14$.

217 RESTATEMENT (SECOND) OF CONTRACTS, supra note 214, § 195(2)(a).

218 See id. § 195(2)(b) (explaining that a term exempting "one charged with a duty of public service from liability to one to whom that duty is owed for compensation for breach of that duty" is unenforceable).

219 Jones v. Dressel, 623 P.2d 370, 376 (Colo. 1981) (citing Rosen v. LTV Recreational Dev., Inc., 569 F.2d 1117 (10th Cir. 1978)); Barker v. Colo. Region- Sports Car Club, Inc., 532 P.2d 372 (Colo. Ct. App. 1974); Threadgill v. Peabody Coal Co., 526 P.2d 676 (Colo. Ct. App. 1974); Ciofalo v. Vic Tanney Gyms, Inc., 177 N.E.2d 925 (N.Y. 1961).

220383 P.2d 441 (Cal. 1963). 


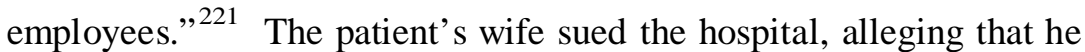
died as a result of the malpractice of doctors employed by the hospital. ${ }^{222}$ The hospital sought to enforce the release of liability. ${ }^{223}$ The California Supreme Court stated the rule that an exculpatory clause that affects the public interest is unenforceable. ${ }^{224}$ It identified a number of factors to consider in determining whether an activity is in the public interest, including the importance to the public of the service performed, whether the exculpated party holds itself out to the public, the economic setting of the transaction, and whether the injured party placed itself in the control of the exculpated party. ${ }^{225}$ The court concluded that the hospital was providing a public service and refused to enforce the release. ${ }^{226}$

Unequal bargaining power used to be almost universally acknowledged as grounds for invalidating an exculpatory clause. ${ }^{227}$ One leading case was Miller's Mutual Fire Insurance Association v. Parker ${ }^{228}$ which addressed an attempt by a parking garage to limit its liability for its negligence when a car was stolen from the garage. ${ }^{229}$ The court refused to limit the garage owner's liability. ${ }^{230}$ It found unequal bargaining power due to the fact that people wishing to park in that part of town frequently could not find parking on the street and had no choice but to use a parking garage. ${ }^{231}$

221 Id. at 442 .

222 Id.

223 Id.

224 Id. at 443.

225 Id. at $445-46$.

226 Id. at 447. Other courts have also held that the provision of medical treatment is a public service for which exculpatory clauses are unenforceable. See, e.g., Leidy v. Deseret Enters., Inc., 381 A.2d 164 (Pa. Super. Ct. 1977) (practicing physical therapy); Olson v. Molzen, 558 S.W.2d 429 (Tenn. 1977) (doctor performing an abortion).

227 See Tunkl, 383 P.2d at 446 n.13. In the law of unconscionability more generally, unequal bargaining power is often the key ingredient in a finding of procedural unconscionability. See also RESTATEMENT (SECOND) OF CONTRACTS, supra note 214, § $208 \mathrm{cmt}$. d ("[G]ross inequality of bargaining power, together with terms unreasonably favorable to the stronger party, may confirm indications that the transaction involved elements of deception or compulsion, or may show that the weaker party had no meaningful choice, no real alternative, or did not in fact assent or appear to assent to the unfair terms.”).

22865 S.E. $2 d 341$ (N.C. 1951).

229 Id. at 344.

230 Id.

231 Id. 
Relying on that case and some earlier cases, the Restatement (Second) of Torts stated that exculpatory clauses would not be enforced "where there is such disparity of bargaining power between the parties that the agreement does not represent a free choice on the part of the plaintiff." ${ }^{232}$ The third Restatement, however, is more circumspect, saying only that "[w]hen an individual plaintiff passively accepts a contract drafted by the defendant, the contract is construed strictly, favoring reasonable interpretations against the defendant." ${ }^{233}$ Following this approach, modern courts seem less inclined to categorically reject exculpatory contracts where the parties are of unequal power. ${ }^{234}$

Even if it is not sufficient to invalidate an agreement, the risk of unequal bargaining power leads courts to scrutinize the language of exculpatory agreements. Many require that a contract use the word "negligence" if it is to be construed as limiting liability for negligence. ${ }^{235}$ The New York Court of Appeals has held that "unless the intention of the parties is expressed in unmistakable language, an exculpatory clause will not be deemed to insulate a party from liability for his own negligent acts.” ${ }^{236}$ The Supreme Court of Texas has applied a broad "fair notice" requirement, which includes both a requirement that the agreement expressly disclaim liability for negligence and also a "conspicuousness requirement."237 Other courts decline to require that the word "negligence" be used but demand a "clear and unequivocal" expression of mutual assent. ${ }^{238}$ The Restatement (Third) of Torts reiterates that test, noting that "[c]ourts normally construe exculpatory contracts strictly, finding that

\footnotetext{
232 ReSTATEMENT (SECOND) OF TORTS § 496B cmt. j (1965).

233 RESTATEMENT (THIRD) OF TORTS: APPORTIONMENT OF Liability $\S 2 \mathrm{cmt}$. d (2000).

234 See, e.g., Crandall v. Bangor Sav. Bank, No. CV-98-239, 1999 Me. Super. LEXIS 304 at *5-6 (Super. Ct. Nov. 4, 1999) ("The law in Maine appears to be that where contracts are presented on a 'take it or leave it' basis and the parties do not have equal bargaining power, the contract may be interpreted to meet the expectations of the party in the inferior bargaining position.") (citation omitted).

235 See, e.g., J.A. Jones Constr. Co. v. City of Dover, 372 A.2d 540, 552 (Del. Super. Ct. 1977).

236 Gross v. Sweet, 400 N.E.2d 306, 309 (N.Y. 1979) (citations omitted).

237 Dresser Indus., Inc. v. Page Petroleum, Inc., 853 S.W.2d 505, 508 (Tex. 1993).

238 Jig the Third Corp. v. Puritan Marine Ins. Underwriters Corp., 519 F.2d 171, 177 n.7 (5th Cir. 1975) (citations omitted).
} 
the plaintiff has assumed a risk only if the terms of the agreement are clear and unequivocal.,239

In sum, courts are very reluctant to enforce contract terms that have the effect of prospectively waiving a party's legal rights or defenses. They never enforce such exculpatory contracts when a party seeks to absolve itself of liability for its intentional torts. They do enforce exculpatory contracts relieving liability for negligence, but not where the absolved party is performing a public service, as in the case of common carriers and providers of medical services, or where the parties are in an employer-employee relationship. Finally, exculpatory agreements must always be manifested in clear, conspicuous, and unambiguous language.

\section{B. Applying the Law of Exculpatory Contracts to - Arbitral Awards}

Courts' uncritical acceptance of arbitral awards runs counter to the law governing exculpatory contracts generally. Every time a court refuses to disturb an award that would be considered remedial legal error if issued by a judge, the court effectively sanctions the prospective waiver of a legal right. ${ }^{240}$ Under the law of contracts, those waivers should be enforced only in limited circumstances. However, courts confirm arbitral awards, many of which must be contrary to law, without regard to circumstances.

The most problematic example of this tendency is the judicial acceptance of arbitration of intentional tort claims. One area in which arbitration is most commonly used is for disputes between securities brokers and their customers. ${ }^{241}$ Many of these disputes involve claims for securities fraud, which is an intentional tort. Under

239 RESTATEMENT (THIRD) OF TORTS, supra note 233, § 2, reporters' note to cmt. d (citations omitted).

240 Another way to understand the problem of waivers of rights in arbitration is through the distinction between mandatory and default legal rules. Mandatory rules are rules that parties cannot contract around. Default rules are rules that apply unless the parties specify some different rule. See Ware, Interstate Arbitration, supra note 22, at 111 . There is no definitive list of mandatory legal rules. In practice, the way a mandatory rule is identified is through a court's refusal to enforce an exculpatory agreement waiving the rule's application. Because the law of exculpatory contracts gives substance to the mandatorydefault distinction, I have chosen to focus on contract doctrine and to avoid generalizing using the mandatory-default labels.

241 See generally Norman S. Poser, When ADR Eclipses Litigation: The Brave New World of Securities Arbitration, 59 BROOK. L. REV. 1095 (1993) (discussing securities arbitration generally). 
standard contract doctrine, a contract exculpating a broker from liability for its fraud would be unenforceable. The federal securities laws make that rule explicit. Both the Securities Act of 1933 and the Securities Exchange Act of 1934 declare void any contract provision waiving compliance with any term of those acts. ${ }^{242}$ The Supreme Court relied on the former provision in Wilko to hold that fraud claims under the 1933 Act were not arbitrable. ${ }^{243}$

First in McMahon, and then in Rodriguez de Quijas, the Court reversed itself and held arbitrable securities fraud claims arising under both Acts as well as under RICO. It emphasized in both cases that the parties were not waiving their substantive rights under the statutes by presenting their cases in arbitration. ${ }^{244}$ But the Court has never faced up to the possibility of arbitral error in those cases. If arbitrators fail to apply the law or misapply the law, and a court refuses to redress the error, parties will have waived compliance with the substantive terms of the statutes.

The same problem arises with respect to employment discrimination, probably the most controversial growth area for arbitration. Employment discrimination is an intentional tort. A party must prove that there was a discriminatory motive for the injurious employment practice. $^{245}$ The Supreme Court in Gilmer held that employment discrimination claims under the ADEA are arbitrable. ${ }^{246}$ Lower courts have extended arbitrability to discrimination claims under the civil rights laws and the Americans with Disabilities Act. ${ }^{247}$

\footnotetext{
24215 U.S.C. §§ 77n, 78cc(a) (2000).

243 Wilko v. Swan, 346 U.S. 427, 434 (1953), overruled by Rodiguez de Quijas v. Shearson/American Express, Inc., 490 U.S. 477 (1989).

244 See Rodriguez de Quijas, 490 U.S. at 482-83; Shearson/American Express, Inc. v. McMahon, 482 U.S. 220, 226 (1987)

245 See 42 U.S.C. § 2000e-2(m) (“[A]n unlawful employment practice is established when the complaining party demonstrates that race, color, religion, sex, or national origin was a motivating factor for any employment practice, even though other factors also motivated the practice.”).

246 Gilmer v. Interstate/Johnson Lane Corp., 500 U.S. 20, 35 (1991).

247 See, e.g., Austin v. Owens-Brockway Glass Container, Inc., 78 F.3d 875, 886 (4th Cir. 1996) (enforcing the arbitration clause that required the parties to arbitrate claims under Title VII and the ADA); Sheth v. Ernst \& Young, L.L.P., No. 04 C 4280, 2005 U.S. Dist. LEXIS 2457, at *6 (N.D. Ill. Jan. 27, 2005) (granting employer's motion to compel arbitration when the employee alleged discrimination under Title VII); Valdes v. Swift Transp. Co., 292 F. Supp. 2d 524, 534 (S.D.N.Y. 2003) (granting defendant's motion to dismiss and ordering arbitration of plaintiff's Title VII claims).
} 
Again, however, the courts have dismissed the problem of arbitral error in these cases. Brown v. ITT Consumer Financial Corp. ${ }^{248}$ is a good example. The plaintiff in Brown had filed a race discrimination claim with the EEOC. ${ }^{249}$ Prior to its resolution, he was terminated. ${ }^{250}$ He then filed suit in district court for discrimination and retaliation, but the district court compelled arbitration pursuant to an arbitration clause in his employment contract. ${ }^{251}$ The arbitrator subsequently denied him relief, and the plaintiff sought vacatur of the award on manifest disregard grounds, arguing that the arbitrator applied the wrong legal test in assessing his retaliation claim. ${ }^{252}$ Both the district court and the Eleventh Circuit upheld the award because the plaintiff had not shown that the arbitrator was conscious of the law and deliberately ignored it. The Eleventh Circuit stated that "[e]ven if the arbitrator applied the wrong standard, which we need not decide, no manifest disregard for the law has been shown, and Brown's argument fails.”,253

It is impossible to know whether the arbitrator in Brown properly applied the standard for retaliation or not, and that is the problem. By declining to consider the possibility of legal error, the Eleventh Circuit gave that arbitrator and others the freedom to deviate from legal standards. Some arbitrators, including perhaps the one in Brown, will take up that offer. To the extent they fail to find discrimination where the law requires, they create a waiver of legal rights that would not be permissible if done by contract.

Similar issues can arise in other common arbitration situations. Providers of medical services have begun to put arbitration clauses into the agreements that patients must sign upon admission. ${ }^{254}$ Courts have been reluctant to enforce those agreements. ${ }^{255}$ But they have left the door open to arbitration of medical malpractice claims as

\footnotetext{
248211 F.3d 1217, 1223-24 (11th Cir. 2000).

249 Id. at 1220.

250 Id.

251 Id. at $1220-21$.

252 Id. at 1223.

253 Id.

254 See Ann H. Nevers, Medical Malpractice Arbitration in the New Millennium: Much Ado About Nothing? 1 PEPP. DisP. RESOL. L.J. 45, 51-52 (2000) (noting that while the "percentage of physicians using [arbitration] agreements was small, it was increasing").

255 See, e.g., Broemmer v. Abortion Servs. of Phoenix, Ltd., 840 P.2d 1013, 1016-17 (Ariz. 1992) (refusing to enforce an agreement requiring a patient to arbitrate her medical malpractice claim against her physician because the agreement appeared in a contract of adhesion and did not involve a conspicuous and explicit waiver of the right to a jury trial).
} 
long as the agreement appeared to be voluntary and the arbitration panel was not biased. ${ }^{256}$ None of the cases has discussed the possibility of arbitral error. Because the provision of medical care is a public service under contract law, an agreement to absolve a medical provider of its negligence would be unenforceable. An arbitral award that erroneously failed to award damages for malpractice would have the same effect.

Finally, arbitration is increasing in the consumer context. ${ }^{257}$ Financial institutions have been especially aggressive in putting arbitration clauses into their standard form contracts. ${ }^{258}$ These are classic contracts of adhesion. The banks have much greater bargaining power than the customers and offer the contracts on a take-it-or-leave-it basis. If these contracts contained provisions waiving the bank's liability, they would be closely scrutinized by courts. $^{259}$ And in fact courts do sometimes hold the arbitration clauses unenforceable when the clauses appear inordinately biased toward the bank. $^{260}$ But courts frequently uphold those clauses, ${ }^{261}$ and again, they have not addressed the possibility of arbitral error.

Because it provides no effective controls over arbitrators, the law of arbitration allows parties to avoid legal rules in ways that they are not permitted under contract law. If the parties could not enter into a contract in which an employee agreed to forgo the right to be free from discrimination, to take one provocative example, then it makes no sense to uphold an "arbitral construction" of their agreement that produced the same result. If anything, the arbitration case is worse, because the party cannot know at the time of contracting exactly what

256 See Thomas B. Metzloff, The Unrealized Potential of Malpractice Arbitration, 31 WAKE FOREST L. REV. 203, 210-11 \& n.45 (1996) (citing cases allowing arbitration of malpractice claims). But see Broemmer, 840 P.2d at 1016-17.

257 See Linda J. Demaine \& Deborah R. Hensler, "Volunteering” to Arbitrate Through Predispute Arbitration Clauses: The Average Consumer's Experience, 67 LAW \& CONTEMP. PROBS. 55, 62 (2004).

258 See id.

259 See, e.g., Turnbough v. Ladner, 754 So. 2d 467, 469 (Miss. 1999) (stating that courts will subject exculpatory language to close judicial scrutiny) (citations omitted); Alack v. Vic Tanny Int'l of Mo., Inc., 923 S.W.2d 330, 334 (Mo. 1996) (stating that future waivers of liability will be strictly construed against the party claiming the waiver). See generally Ann Springer, Releases: An Added Measure of Protection from Liability, 39 BAYLOR L. REV. 487 (1987) (explaining liability releases).

260 See Patterson v. ITT Consumer Fin. Corp., 18 Cal. Rptr. 2d 563, 567 (Cal. Ct. App. 1993).

261 See Herrington v. Union Planters Bank, N.A., 113 F. Supp. 2d 1026, 1035 (S.D. Miss. 2000); Marsh v. First USA Bank, N.A., 103 F. Supp. 2d 909, 926 (N.D. Tex. 2000). 
rights it might be forfeiting. The courts have simply failed to recognize this problem.

IV

\section{PARTY AUTONOMY AND JUDICIAL REVIEW: IDENTIFYING THE ALTERNATIVE THE PARTIES BARGAINED FOR}

Taken to its logical conclusion, my contract law argument entails a heightened standard of review for any arbitral award raising the sorts of issues implicated by the law of exculpatory contracts. Certainly the simplest way to address the potential for improper avoidance of legal rules through arbitration is to require de novo judicial review of all mandatory legal rules raised in arbitration. A number of scholars concerned about the loss of due process entailed by binding arbitration of public law disputes have argued for that result. In his critique of the privatization of law through arbitration, Professor Stephen Ware argued that courts must either refuse to enforce agreements to arbitrate disputes implicating mandatory legal rules or require de novo review of awards in those cases. ${ }^{262}$ Other commentators have suggested applying standards of review that fall between the current policy of complete deference and a de novo standard. A typical example would require vacatur if an award "egregiously departs from established legal principles." 263

Despite its logical appeal, the solution of heightening standards of review across the board-either to a de novo or some lesser standard-is neither practicable nor desirable. It is impracticable because of courts' overwhelming embrace of unreviewable arbitration. To this point, courts have shown little interest in expanding their oversight role with respect to arbitration. While a limited increase in judicial review may be feasible, a dramatic and broad increase is not. And even if courts were willing to take on a greater oversight role, an across-the-board increase in judicial review would not be desirable because it would unnecessarily constrict party autonomy in the selection of dispute resolution processes.

Although we say that parties cannot agree to avoid the operation of mandatory legal rules, in fact, they do so routinely. That is precisely what settlement entails. Adjudication is, in most instances, a zerosum game. Courts resolve disputes by finding that the parties either

\footnotetext{
262 See Ware, supra note 13, at 704.

263 Poser, supra note 130, at 473.
} 
did or did not violate their legal duties. ${ }^{264}$ When parties settle lawsuits, they agree to avoid those determinations. They agree, in other words, to an outcome different from the one that would be produced by the application of legal rules through adjudication. ${ }^{265}$ Only in rare cases do courts scrutinize settlements, even when the claims involve mandatory legal rules. ${ }^{266}$ Every time they settle a claim involving mandatory legal rules in a way that does not match the adjudicative outcome that would have resulted, the parties have agreed to avoid the law.

We seem to be comfortable with those outcomes for several reasons. Settlements come after legal rights have matured. At that point in the process, we assume that the parties have full information regarding the rights they might be forgoing. ${ }^{267}$ Furthermore, we assume that the structure of the system-particularly the availability of contingency fee arrangements-ensures a relatively level playing field on which the parties can negotiate. ${ }^{268}$ The agreement to avoid the operation of legal rules has relatively strong indicia of voluntariness. Parties can sometimes be bludgeoned into settlement of meritorious claims by threats of protracted and expensive

264 For a general critique of this feature of adjudication, see John E. Coons, Approaches to Court Imposed Compromise-The Uses of Doubt and Reason, 58 NW. U. L. REV. 750 (1964).

265 This is true even when the parties consciously construct settlement parameters based on the likely adjudicative outcome. In setting reservation prices for use in negotiating a settlement, the parties derive an expected value for the case by multiplying the expected recovery by the likelihood of achieving that recovery. See Russell Korobkin, A Positive Theory of Legal Negotiation, 88 GEO. L.J. 1789, 1792-93 (2000). That expected value is not the actual expected recovery in that case. It is, instead, the average recovery that could be expected if the case were litigated many times. See RUSSELL KOROBKIN, NEGOTIATION THEORY AND STRATEGY 46 (2002). However, it probably does not reflect the real consequences of application of the salient legal rules in any one case.

266 See, e.g., Antitrust Penalties \& Procedures Act of 1974, 15 U.S.C. § 16(e)(1) (2000) (requiring a judge to decide whether antitrust settlements proposed by the United States are "in the public interest”); Fed. R. Civ. P. 23(e)(1)(A) (requiring court approval for settlement of class actions).

267 Carrie Menkel-Meadow, Whose Dispute Is It Anyway?: A Philosophical and Democratic Defense of Settlement (In Some Cases), 83 GEO. L.J. 2663, 2677 (1995) ("Even those settlements that actively and intentionally seem to depart from the law are accomplished precisely because a potential legal result has been considered (and is, thus, still a reference point) and has been rejected.”).

268 But see Owen M. Fiss, Against Settlement, 93 YALE L.J. 1073, 1076-77 (1984). Fiss argues that power imbalances often result in coerced settlements. Id. The availability of contingent fees does not fully rectify those imbalances because contingent fees are available only to plaintiffs and only in certain types of cases. Id. at 1077. 
litigation. $^{269}$ But the availability of contingency fees and the default rule requiring each party to pay its own attorneys' fees reduce concerns about coerced settlements.

It is a very different thing for parties to agree prospectivelybefore their rights have accrued — to forgo legal rights. The parties lack complete information at that point, and the potential for power imbalances may make the waiver of rights only nominally voluntary. Thus, for example, parties cannot agree prior to the accrual of a cause of action to extend a statute of limitations, but they can agree to extend the limitations period after the cause of action has accrued. ${ }^{270}$

Arbitration presents a case somewhere between the extremes of settlement on the one hand and explicit prospective waiver of rights on the other. My premise that parties may be understood to have agreed ex ante on the terms of the award ultimately rendered by the arbitrator is a fiction. In fact, the parties undoubtedly go into the arbitration hoping for a favorable decision, and many times they get it. When they agree to arbitrate, they do not agree to forgo their rights. Instead they agree to accept the chance that they will forgo their rights. This choice is problematic, but it is less problematic than an express waiver of rights in an exculpatory agreement would be.

Concerns about the waiver of legal rights through arbitration can be addressed with a relatively modest change in judicial approach to confirmation of awards. First, the cases on exculpatory contracts offer guidance as to the kinds of cases in which the prospective waiver of legal rights raises sufficient concerns to warrant a heightened standard of review. Waivers that amount to consent to an intentional injury, involve the provision of public services, or occur between parties with dramatically different bargaining power raise special concerns. On the other hand, where these factors are not present, waivers of legal rights may promote social goals including efficiency and conservation of judicial resources.

Further, the Supreme Court's arbitration cases suggest a division between statutory rules on the one hand, and procedural and commonlaw rules on the other. In discussing the requirement that arbitrators apply legal rules, the Court has focused entirely on statutory commands, such as those contained in the securities laws, the antitrust

\footnotetext{
269 See id. at 1075.

270 See, e.g., N.Y. C.P.L.R. 201 (McKinney 2005) (“An action . . . must be commenced within the time specified in this article unless a different time is prescribed by law or $a$ shorter time is prescribed by written agreement.") (emphasis added).
} 
laws, the discrimination laws, and RICO. It has never admonished arbitrators to follow procedural or common-law rules in the same way.

Statutory rights have, correspondingly, become a focal point for scholars calling for greater judicial scrutiny of awards. ${ }^{271}$ While a focus on statutory rights may come at a cost in analytic principle, ${ }^{272}$ it simplifies the process of determining when additional judicial review is warranted and narrows the range of cases in which that review will occur. $^{273}$ A proposal that targets only statutory rights thus has a better chance of acceptance and implementation than one that addresses mandatory rules more generally. For that reason, I suggest that arbitral awards implicating procedural and common-law rules should receive little or no additional scrutiny, while those implicating statutory rules merit greater solicitude.

These principles suggest a flexible approach to the problem of law avoidance through arbitration. Rather than adopting a heightened standard of review in all cases, courts need to treat cases differently depending first on the legal rules involved, and then on the relationship of the parties and the nature of their dispute. Only cases implicating statutory rules of the kind disfavored in the law governing exculpatory contracts warrant any additional judicial review. Where those important statutory rights are at issue and the parties have entered into an agreement to arbitrate, I propose a three-level approach to judicial review. The approach turns on whether the parties are of equal or unequal bargaining power and whether the

271 See, e.g., Richard E. Speidel, Arbitration of Statutory Rights Under the Federal Arbitration Act: The Case for Reform, 4 OHIO ST. J. ON DISP. RESOL. 157, 210 (1989). Professor Speidel argues that courts should not be precluded from reviewing an arbitrator's decision determining federal statutory rights. Id. However, he would preclude review when it can be shown that the arbitral procedures were substantially similar to those used in litigation, and the arbitrator actually decided the facts and the legal questions. Id.

272 See Edward M. Morgan, Contract Theory and the Sources of Rights: An Approach to the Arbitrability Question, 60 S. CAL. L. REV. 1059, 1076 (1987). "It is evident that there is no necessary distinction between the substance of common law and statutory provisions." Id.

273 Cf. Ware, supra note 13, at 732-33. Professor Ware argues that the proper distinction is between mandatory and default rules. Id. In other words, he would apply a heightened standard of review to any rules-whether statutory or common-law-that are not waivable under the law of contract. See id. His position has logical appeal. I have not adopted it for reasons that are purely pragmatic: I believe the proposal that has the best chance for adoption is the one that calls for the least change from the status quo. 
circumstances suggest the existence of an ongoing relationship. ${ }^{274}$ Using these factors, I place arbitrations in three categories: (1) those in which the parties have roughly equal bargaining power and are in an ongoing relationship, (2) those in which the parties have roughly equal bargaining power but no ongoing relationship, and (3) those in which the parties have substantially unequal bargaining power.

My objective in categorizing arbitrations this way is to find criteria that can serve as useful indicators of party intent. We can assume parties choose arbitration at least because they desire an alternative to formal adjudicative process. The question then becomes the extent to which the parties seek, voluntarily and with full information, an alternative to law. I will suggest different standards of review that should presumptively apply to the arbitrations in these classes.

For purposes of this discussion, I will assume that the parties have substantially disparate bargaining power whenever one side has no meaningful opportunity to influence the terms of the agreement. Given this definition, unequal bargaining power would exist with respect to all contracts of adhesion, including consumer contracts relating to everything from computer equipment to financial services to medical care. It would also exist with respect to any employment contract in which the employee has insufficient leverage to materially affect the terms of the agreement.

I measure the existence of an ongoing relationship as of the time of the arbitration rather than the time of contracting. If the parties contemplated an ongoing relationship in the contract, but the relationship has soured past the point of reconciliation, then creative remedies an arbitrator might otherwise attempt to find become extraneous. The contract is, in effect, modified, and the arbitrator should take that fact into account.

\section{A. Equal Bargaining Power, Ongoing Relationship}

Formal adjudication is by its nature a combative enterprise. Success depends on proving that the other side either did something wrong or is wrong in alleging that it suffered a remediable harm. A certain amount of bitterness is almost certain to result from such a

274 See Hugh Baxter, Habermas's Discourse Theory of Law and Democracy, 50 BUFF. L. REV. 205, 278 (2002) ("The parallel in the bargaining situation is that the parties must have 'equal opportunity for pressure,' that is, equal bargaining power.”). See generally Daniel D. Barnhizer, Inequality of Bargaining Power, 76 U. COLO. L. REV. 139 (2005) (discussing bargaining power and the effects of unequal bargaining power). 
contest. For that reason, people who have an interest in maintaining a relationship have especially powerful reasons for seeking alternative dispute resolution mechanisms such as arbitration.

Parties in that situation normally will want more than just an alternative to formal adjudicative processes. They will also want an alternative to the application of legal rules, because legal rules tend to provide binary solutions. Rather than hoping for a finding that a contracting partner committed fraud, for instance, parties to these disputes often want a restructuring of their relationship that will produce mutual benefits. When their negotiations break down, they want a neutral to supply the terms that they should have agreed towhether or not those terms would be the ones the law would require. As long as the parties have roughly equivalent bargaining power, there is no good reason to bar parties in this situation from avoiding law through arbitration.

The two contexts in which arbitration has historically thrived most-commercial disputes and labor-management relations-fit this paradigm. In both contexts, most of the time the parties bring bargaining power to the table and anticipate further interaction. They have reason to minimize conflict even if that means forgoing certain legal rights to which they might be entitled.

Not coincidentally, this situation-parties with equal bargaining power in an ongoing relationship-seems to be the one that best fits within the statutory structure of the FAA. Where it is appropriate for the parties to avoid law, the only review required under the FAA is what is necessary to make sure that the arbitrator does not exceed his authority, possess bias, or direct the parties to do something illegal. ${ }^{275}$ If arbitration were limited to commercial disputes and labormanagement relations, this level of review would be entirely appropriate. But it is not. As arbitration has expanded, the parties to arbitration agreements may lack either or both equal bargaining power and an ongoing relationship.

\section{B. Equal Bargaining Power, No Ongoing Relationship}

Frequently parties with equal bargaining power will choose arbitration in the absence of an ongoing relationship. Commercial disputes fall into this class where the parties have a finite agreement or where the relationship has irreparably deteriorated. Large investors

275 See 9 U.S.C. § 10 (2000 \& Supp. II 2001-2003). 
and their securities brokers may also find themselves in this situation, as may powerful employees and their employers.

In these cases, there is reason to think that the parties selected arbitration voluntarily and with full information. To that extent, it makes sense to treat the arbitrator's award as a manifestation of the parties' mutual intent. This class is different from the first class, however, because the parties have less incentive to avoid the adversarialism of adjudication. Without the lure of benefits from future dealings, the parties will frequently want a declaration of their rights and obligations, and they may expect the arbitrator to provide one. At least some of the time, the parties will see the outcome of the arbitration as a win for one and a loss for the other. To that extent, it makes less sense to treat the award as a manifestation of the parties' mutual intent.

Still, if arbitrations falling in the first class call for the minimum in judicial review, arbitrations in this class call for only slightly more. One important reason why parties have traditionally selected arbitration as a dispute resolution mechanism is that they want a decision maker who will apply industry standards instead of legal rules. Among merchants, for example, certain disputes are resolved almost exclusively with arbitrators who apply customary standards rather than legal rules. ${ }^{276}$ In many cases, these disputants want a decision maker to determine who is right and who is wrong, but they do not want that decision to be made by reference to legal rules.

For these arbitrations, the manifest disregard test should supplement the "essence" test and the public policy ground as an additional standard of judicial review. Under the manifest disregard test, as it is most commonly understood, an award may be disturbed only if the arbitrator acknowledges a legal rule and then ignores it. ${ }^{277}$ Where parties have roughly equal bargaining power, it makes sense to assume that they voluntarily and knowingly entrust their dispute to the arbitrator. If the arbitrator chooses not to decide the dispute by reference to generally applicable legal rules, the parties may be understood to acquiesce in that choice. On the other hand, if the arbitrator chooses to apply legal rules, the parties may be understood to demand that he or she actually apply them. In such a case, the

\footnotetext{
276 See William Catron Jones, Three Centuries of Commercial Arbitration in New York: A Brief Survey, 1956 WASH. U. L. Q. 193, 218-19.

277 See Poser, supra note 130, at 504-05.
} 
manifest disregard of the legal rules would contravene the parties' intentions.

\section{Unequal Bargaining Power}

Increasingly, arbitration clauses appear in agreements between parties with dramatically different bargaining power, whether or not they are engaged in an ongoing relationship. ${ }^{278}$ This class includes most consumer arbitrations, including most securities arbitrations, and a great many employer-employee arbitrations. These are the cases in which the contractarian model of arbitration is least apposite. Almost by definition, the parties have different interests, so the "agent" of one cannot simultaneously be the "agent" of the other, as the contractarian model assumes.

The courts have moved far beyond the point at which the enforceability of arbitration agreements in these situations is open to serious question. The Supreme Court is firmly committed to arbitration as an alternative to formal adjudication. It has refused to entertain arguments that arbitration is an inadequate substitute even for contracts of adhesion. ${ }^{279}$ As a matter of arbitration doctrine, an agreement to arbitrate amounts to a statement of the parties' intention to avoid formal adjudication.

But the agreement to forgo formal adjudication does not necessarily entail an agreement to forgo the application of legal rules. This is the point at which the prevailing model of judicial review breaks down. In cases in which the parties to an agreement to arbitrate have significantly disparate bargaining power, a presumption should apply that the parties desire some minimal level of substantive judicial review to protect against clear errors of law.

The question, of course, is what level of review to apply. Giving courts the power to review the legal decisions of arbitrators de novo-as appellate courts review trial judges' decisions on legal issues-would effectively defeat arbitration as an effective alternative to formal adjudication. Any party disappointed with the award could subject the other party to the equivalent of a formal appeal in virtually any case. This result could, in the end, hurt the weaker party more

278 Where there is such a disparity of bargaining power, the stronger party will have the ability to dictate the terms of the agreement, including the possibility of extending the relationship. Thus, the contemplation of an ongoing relationship cannot be assumed to be voluntary and mutually intended.

279 See Gilmer v. Interstate/Johnson Lane Corp., 500 U.S. 20, 26 (1991). 
than the stronger. Some studies have shown that arbitration is good for employees with discrimination claims, for example, because its low cost allows the pursuit of smaller or more speculative claims that no plaintiff's lawyer operating on a contingency fee would pursue in court. $^{280}$ That advantage could be lost if every employee who won in arbitration faced the prospect of a further round of litigation in court.

But some lower standard of review could ensure basic compliance with legal rules while retaining the effectiveness of arbitration. Several other lower standards would suffice. For example, trial judges review the decisions of juries by asking whether a reasonable jury could decide the way the jury decided. ${ }^{281}$ Appellate courts review the factual determinations of trial judges by asking whether the judge abused his or her discretion. ${ }^{282}$ Courts review the determinations of administrative agencies by asking whether the agency's decision is arbitrary and capricious. ${ }^{283}$ It is not clear what difference, if any, there is among these standards. Each requires deference to the lower decision maker, and each applies some version of a test of rationality. Any of the three could be adopted, as could an explicit rationality standard. The exact wording of the test is not especially significant as long as the court has the power to correct clear and important errors of law.

Implicit in this discussion is the principle that the arbitrator's factual findings should be free from judicial review outside of the traditional grounds. The arbitrator's factual findings provide the background for his or her decision on the parties' rights and responsibilities. Under a contractarian model, those findings are the equivalent of the recitals in a contract. Contract law prevents parties from bargaining away certain legal rights in certain circumstances. It says nothing about the factual premises on which the parties base their agreements.

\footnotetext{
280 See Samuel Estreicher, Saturns for Rickshaws: The Stakes in the Debate over Predispute Employment Arbitration Agreements, 16 OHIO ST. J. ON DISP. RESOL. 559, 563-64 (2001).

281 See Jack H. Friedenthal ET AL., Civil Procedure $\S 13.4$ (4th ed. 2005) (describing the nature and scope of review).

282 Id.

283 See Marsh v. Or. Natural Res. Council, 490 U.S. 360, 377 \& n.23 (1989) (stating that the applicable standard of review for administrative agency determinations is the arbitrary and capricious standard); Neiman v. Sec’y of Dep’t of Health \& Human Servs., 722 F. Supp. 954, 957 (E.D.N.Y. 1988) (reviewing the administrative agency’s determination under the arbitrary and capricious standard).
} 
Even though courts have no reason to review the arbitrator's factual findings, my proposal would require arbitrators to memorialize their factual findings and legal conclusions in order to allow for meaningful judicial review of the legal issues. There seems to be a trend in this direction anyway, ${ }^{284}$ but it represents a change from traditional practice, in which arbitrators were expressly encouraged not to create a reviewable record. ${ }^{285}$ From my perspective, this change would be a positive one. The requirement of writing a reasoned opinion has long served as an important guarantor of adjudicative fairness. Where arbitrators are called on to decide the sorts of statutory issues traditionally reserved for courts, and the parties' relationship indicates an intention to apply legal rules to the dispute, the arbitrators should provide reasons for their decisions.

The heightened standard of review I propose should apply regardless of the terms purportedly agreed upon in the arbitration clause. Again, my argument is that the parties should not be permitted to prospectively waive their rights to the application of statutory rules in these cases. That is, they should not be able to contract away judicial review even if they attempt to do so expressly in the agreement.

On the other hand, once the rights in question have matured and the parties have reached the point of arbitration, the waiver calculus changes. A waiver of rights after a legal cause of action has matured is simply a settlement. If the parties mutually decide to give an arbitrator the freedom to disregard the law at that point-or if they simply want to guarantee that their dispute will not reach a courttheir wishes should be honored unless a settlement in similar circumstances would be disallowed. ${ }^{286}$ The heightened standard of

\footnotetext{
284 See Covington, supra note 13, at 394-95 (citing various recommendations for written opinions in at least some types of arbitrations). See also Christopher B. Kaczmarek, Public Law Deserves Public Justice: Why Public Law Arbitrators Should Be Required to Issue Written, Publishable Opinions, 4 EMP. RTS. \& EMP. POL'Y J. 285, 287 (2000) (arguing for written, publicly available opinions in cases involving issues of public law).

285 See American Arbitration Ass'n Guide for Commercial Arbitrators (2006), http://www.adr.org/sp.asp?id=22016. The AAA Guide makes clear that arbitrators are not required to provide written opinions, emphasizing that "a carelessly expressed thought in a written opinion could afford an opportunity to delay enforcement of the award. The obligations to the parties are better fulfilled when the award leaves no room for attack." Id.

${ }^{286}$ Cf. Ware, supra note 13, at 728-29. Professor Ware argues for de novo review of awards implicating mandatory legal rules but not for postdispute agreements to arbitrate. See also Ware, Interstate Arbitration, supra note 22, at 111.
} 
review, then, should apply presumptively only. Courts should assume that they have an obligation to review arbitral determinations on statutory rules of law for irrationality (or some comparable standard) unless the parties expressly agree to a different standard after their dispute reaches the point of arbitration.

That raises the question of whether parties can dictate terms of review to courts. There is no clear consensus on this issue. Several circuits, most prominently the Ninth Circuit in Kyocera Corp. $v$. Prudential-Bache Trade Services, Inc., ${ }^{287}$ have held that parties may not contract for judicial review beyond that contained in section 10 of the FAA. ${ }^{288}$ Other circuits, including the Fourth and Fifth, allow the parties to contract for additional review. ${ }^{289}$ All the cases raising this issue involve attempts by parties to heighten the review that a court would otherwise provide. My proposal does not necessarily implicate those cases. I am arguing that review for irrationality or arbitrariness should be part of courts' residual common-law authority over arbitration. If parties want a degree of review more exacting, then they run into the Kyocera line of cases. ${ }^{290}$ But my primary concern is that parties have the freedom to avoid judicial review if they so desire. Just as parties are normally free to opt out of litigation by choosing arbitration in the first instance, so they should be free to opt out of judicial review of arbitral awards as long as they do so after the legal rights in question have matured. ${ }^{291}$

287341 F.3d 987 (9th Cir. 2003) (en banc).

288 See also Bowen v. Amoco Pipeline Co., 254 F.3d 925, 940 (10th Cir. 2001). The Seventh and Eighth Circuits have suggested in dicta that parties should not be entitled to contract for heightened review. See UHC Mgmt. Co. v. Computer Scis. Corp., 148 F.3d 992, 998 (8th Cir. 1998); Chicago Typographical Union No. 16 v. Chicago Sun-Times, Inc., 935 F.2d 1501, 1505 (7th Cir. 1991).

289 See Hughes Training, Inc. v. Cook, 254 F.3d 588, 592-93 (5th Cir. 2001); Syncor Int'l Corp. v. McLeland, No. 96-2261, 1997 U.S. App. LEXIS 21248, at *17 (4th Cir. Aug. 11, 1997).

290 See generally Jonathan R. Bunch, Arbitration Clauses Should Be Enforced According to Their Terms-Except When They Shouldn't Be: The Ninth Circuit Limits Parties' Ability to Contract for Standards of Review of Arbitration Awards, 2004 J. DISP. RESOL. 461 (discussing conflicting case law on parties' right to contract for higher standard of review than provided in FAA).

291 There is a fundamental difference between contracting for judicial review and contracting to avoid judicial review. Parties cannot contract to give courts power to hear claims that are beyond the court's subject matter jurisdiction. See, e.g., Chicago Typographical, 935 F.2d at 1505 ("[Parties] cannot contract for judicial review of [an arbitral] award; federal jurisdiction cannot be created by contract.”). But they are normally free to waive their rights to adjudicative process. For example, parties can forgo 


\section{CONCLUSION}

The argument I have made in this Article rests on a particular way of conceptualizing arbitration. I take a model that sees the arbitrator as the parties' agent for interpreting their agreement, what I call the contractarian model, and tease out the implications that follow from a rigorous application of that model. I assume that the arbitrator's award may be understood as equivalent to a contract term agreed upon by the parties ex ante. I then argue that if the award would be unenforceable as an exculpatory contract if its terms were included in the agreement, it does not deserve the extreme judicial deference normally applied. I suggest that a presumptively higher, although still quite deferential, standard of review should apply when an arbitration involves parties whose relationship raises concerns about the prospective waiver of legal rights.

The contractarian model is merely one way of conceptualizing arbitration. For an observer who sees arbitration simply as private adjudication, the model loses force and so does my argument. I have explained why I believe the contractarian model is a valid and useful way of understanding arbitration. But I want to emphasize that I believe the adoption of a private adjudication model would raise even more fundamental concerns. This is an argument convincingly made by Richard Rueben, who has contended that arbitration, in at least

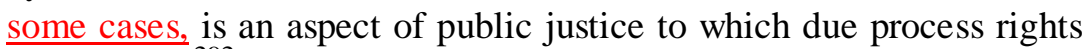
must apply. ${ }^{292}$ My objective, in part, is to demonstrate that these concerns do not disappear if arbitration is conceptualized as a species of contract rather than adjudication.

Understandable frustration with high litigation costs, crowded court dockets, and unpredictable juries has led to the judicial embrace of essentially unreviewable arbitration. The change in judicial attitudes and the corresponding expansion of arbitration have

jurisdiction in a particular court by agreeing to a forum selection clause. See FRIEDENTHAL ET AL., supra note 281, § 3.5.

292 See Richard C. Reuben, Public Justice: Toward a State Action Theory of Alternative Dispute Resolution, 85 CAL. L. REV. 577, 609-41 (1997). Moreover, other commentators have made similar arguments without expressly equating arbitration with adjudication. See Jean R. Sternlight, Rethinking the Constitutionality of the Supreme Court's Preference for Binding Arbitration: A Fresh Assessment of Jury Trial, Separation of Powers, and Due Process Concerns, 72 Tul. L. REV. 1, 10 (1997). But see MedValUSA Health Programs, Inc. v. MemberWorks, Inc., 872 A.2d 423, 428 (Conn. 2005) (holding that a judicially confirmed arbitration award granting punitive damages is exempt from due process limits because judicial confirmation is not a state action). 
occurred very rapidly. As a result, the full implications of the arbitration-based dispute resolution system have not been explored. This Article points out one significant way in which the modern law of arbitration clashes with bedrock principles of contract law. It cannot and does not pretend to answer the many policy questions raised by the growth of arbitration. But it provides a concrete doctrinal reason why courts need to be more active in their scrutiny of arbitral awards than they have become accustomed to. 